\title{
WHAT, WHEN AND WHY TO OUTSOURCE HELP IS ON THE WAY
}

\author{
by \\ Keith B. Shoates, Major, USAF \\ A Research Report Submitted to the Faculty \\ In Partial Fulfillment of the Graduation Requirements
}

Advisor: Lt Col Jeffery R. Garner

Maxwell Air Force Base, Alabama

April 1999 


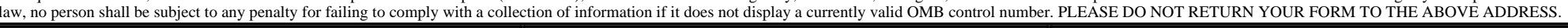
1. REPORT DATE (DD-MM-YYYY) 01-04-1999

2. REPORT TYPE

Thesis

4. TITLE AND SUBTITLE

What, When and Why to Outsource Help is on the Way

Unclassified

6. AUTHOR(S)

Shoates, Keith B. ;

7. PERFORMING ORGANIZATION NAME AND ADDRESS

Air Command and Staff College

Maxwell AFB, AL36112

9. SPONSORING/MONITORING AGENCY NAME AND ADDRESS

12. DISTRIBUTION/AVAILABILITY STATEMENT

APUBLIC RELEASE

\section{SUPPLEMENTARY NOTES}

14. ABSTRACT

How does one identify which functions to outsource, why and to what degree? This paper hypothesizes that a decision support model tied to the Air Force Core Competencies, strategic environment, and objective criteria drawn from successful outsourcing activities may be the answer when oftentimes competing goals and objectives of the primary stakeholders is involved. The model supports the Air Force Program Manager (PM) in rapidly making the decision to outsource (or not) by providing a systematic approach that incorporates a hierarchical process and decision support tools, integrating the key stakeholders in the decision process, and providing flexibility to the program managers by allowing tailoring of the process and information to meet unique circumstances. Laying out some of the important factors that should be considered in planning to outsource a particular function, the model is descriptive rather that predictive.

15. SUBJECT TERMS

16. SECURITY CLASSIFICATION OF: 5a. CONTRACT NUMBER

5b. GRANT NUMBER

5c. PROGRAM ELEMENT NUMBER

5d. PROJECT NUMBER

5e. TASK NUMBER

5f. WORK UNIT NUMBER

8. PERFORMING ORGANIZATION REPORT

NUMBER

10. SPONSOR/MONITOR'S ACRONYM(S)

11. SPONSOR/MONITOR'S REPORT

$\operatorname{NUMBER}(\mathrm{S})$
a. REPORT
Unclassified
b. ABSTRACT c. THIS PAGE
Unclassified

\begin{tabular}{l|l|l|}
$\begin{array}{l}\text { a. REPORT } \\
\text { Unclassified }\end{array}$ & $\begin{array}{l}\text { b. ABSTRACT } \\
\text { Unclassified }\end{array}$ & $\begin{array}{l}\text { c. THIS PAGE } \\
\text { Unclassified }\end{array}$
\end{tabular}

17. LIMITATION OF ABSTRACT Public Release

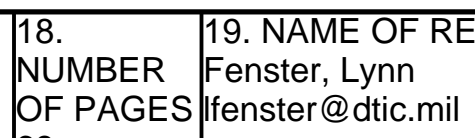

18. NUMBER Fenster, Lynn OF PAGES |fenster@dtic.mil

19b. TELEPHONE NUMBER

International Area Code

Area Code Telephone Number

703767-9007

DSN

427-9007 


\section{Disclaimer}

The views expressed in this academic research paper are those of the author(s) and do not reflect the official policy or position of the US government or the Department of Defense. In accordance with Air Force Instruction 51-303, it is not copyrighted, but is the property of the United States government. 


\section{Contents}

Page

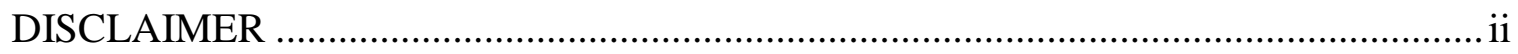

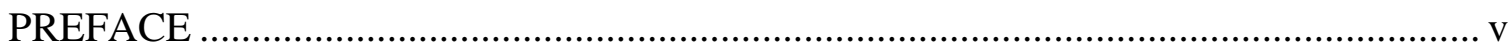

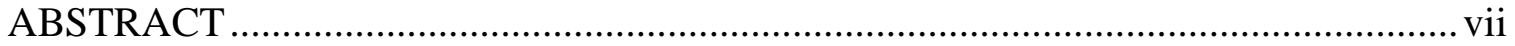

Purpose/Problem Statement .................................................................................. vii

Research Method/Approach................................................................................... vii

Preview of Methodology................................................................................ viii

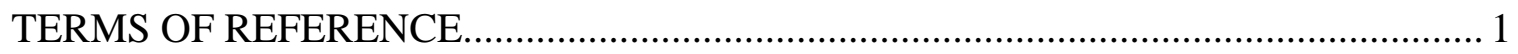

Definition of Terms.................................................................................. 1

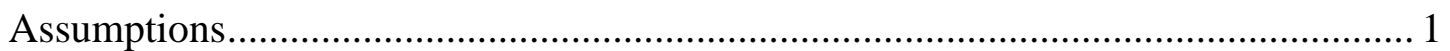

Limitations of Data and Accompanying Analysis ................................................... 2

BACKGROUND AND SIGNIFICANCE OF PROBLEM …....................................... 4

Air Force Budget History .................................................................................... 4

Savings and Cost Avoidance via Outsourcing .......................................................... 5

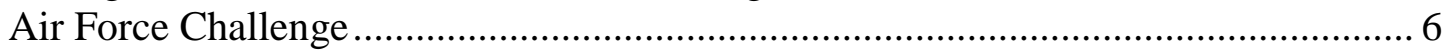

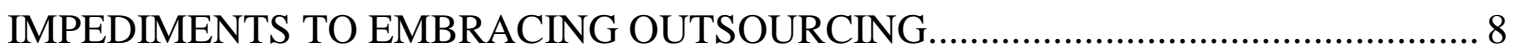

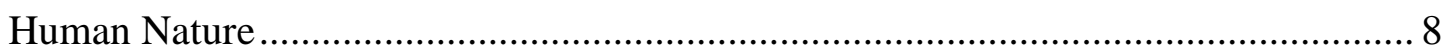

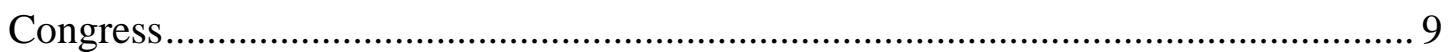

Department of Defense/Military Services................................................................. 10

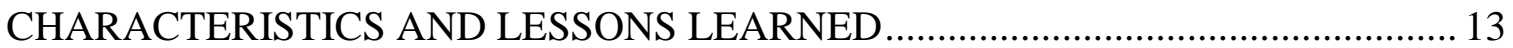

Department of Defense/Military Services.............................................................. 13

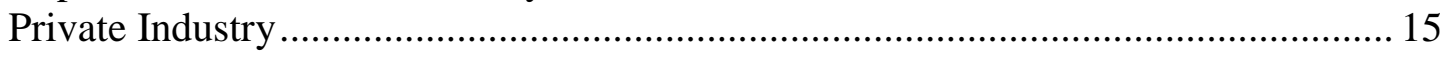

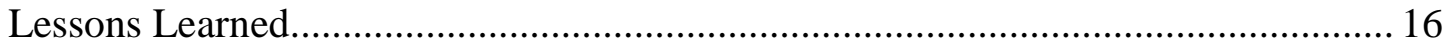

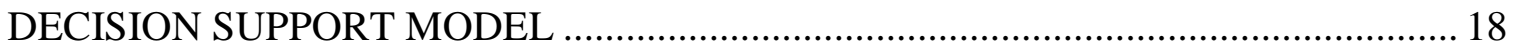

Why Is The Decision Support Model Significant? ................................................ 18

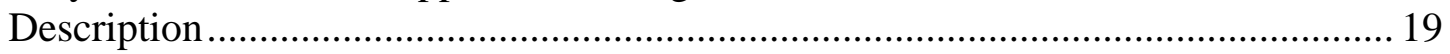

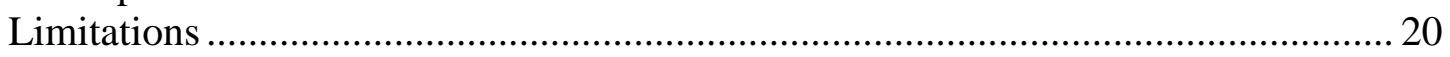

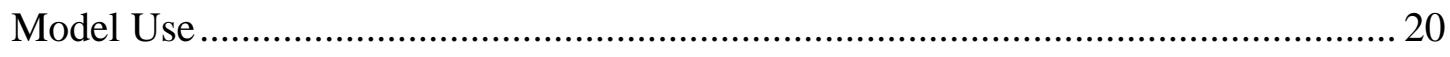

Why Are The Process, Software, And Participants Significant?................................. 21

MODEL TEST CASE: NATIONAL LAUNCH RANGE.............................................. 24

Description of Test Case ………………………………….................................. 24 


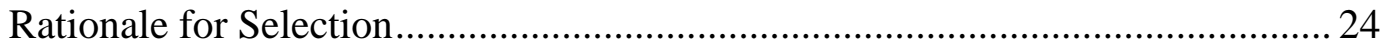

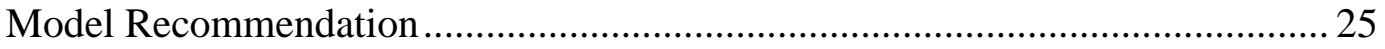

Assessment of Model Results ......................................................................... 26

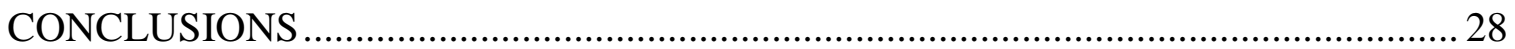

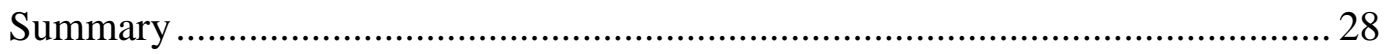

Relationship to Purpose/Problem Statement.................................................... 29

APPENDIX A: BASE OPERATING SUPPORT FUNCTIONS ….............................. 31

APPENDIX B: QUESTIONS FOR ANALYTICAL \& DEDUCTIVE PROCESS ......... 33

APPENDIX C: CONTROL, LOGIC, STRUCTURE, AND EFFICIENCY .................. 38

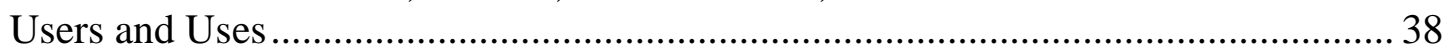

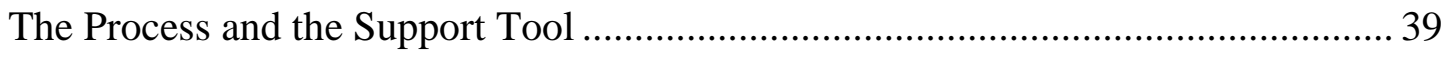

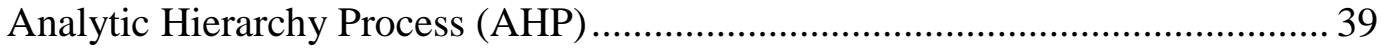

Team Expert Choice Software ..................................................................... 40

APPENDIX D: PROCESS EXECUTION STEPS …............................................ 41

Step 1: Reach Common Understanding ........................................................ 41

Step 2: Determine Criterion Weights............................................................ 41

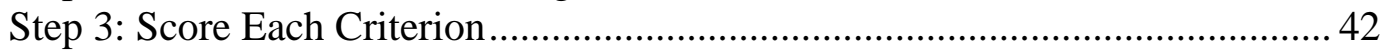

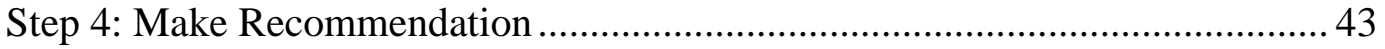

APPENDIX E: ASSESSMENT MATRIX (GENERIC) …....................................... 44

APPENDIX F: ASSESSMENT MATRIX (NATIONAL LAUNCH RANGE)............... 51

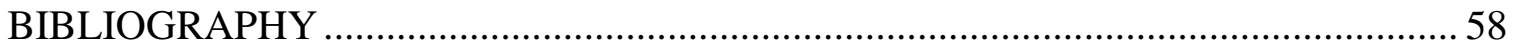




\section{Preface}

The topic of this paper was chosen after gaining an understanding of the Air Force Core Competencies (i.e., Air and Space Superiority, Global Attack, Rapid Global Mobility, Precision Engagement, Information Superiority, and Agile Combat Support). Additionally, following presentations by the Acting Secretary of the Air Force, Air Force Chief of Staff, and the Commandant of the Marine Corps it became apparent that funding sustainment, while simultaneously modernizing the force structure, is a challenge. However, both must be done simultaneously with a flat or decreasing share of the national budget. ${ }^{1}$ In fact, Secretary of Defense Cohen stressed "the Department of Defense does not have the luxury to choose between shaping and responding in the near term and transforming itself for the future. We must do both." ${ }^{2}$ However, conspicuous by its absence, there is no Air Force Core Competency that stresses the criticality of a Revolution in Business Affairs (i.e., RIBA) or acquisition excellence to field the systems consistent with the existing Air Force Core Competencies or Joint Vision (i.e., JV) 2010. Thus, this paper is intended to bring an aspect of RIBA - namely outsourcing within the Air Force - to the forefront. It provides a tool (i.e., Model) for determining what functions should be outsourced to meet the funding shortfalls in order to implement JV 2010.

This paper would have been significantly different without the constant constructive guidance provided by my faculty advisor, Lt Col Jeffery Garner. Because Lt 
Col Garner did not impose his beliefs regarding the subject matter, I was able to develop the thesis based on personal domain knowledge and interest in the subject matter. By providing incremental feedback as each section of the paper was completed, Lt Col Garner enabled me to revised sections as necessary and to remain focused. Additional appreciation is extended to Headquarters Air Force Space Command (AFSPC/XPMH) for providing the initial data that focused my research. Also, special thanks are extended to both Air Force Materiel Command/Space and Missile Systems Center/Satellite Control and Data Handling Program Office and the National Reconnaissance Office for invaluable assistance as my experience base for much of my government-related domain specific knowledge. Finally, thanks are extended to AT\&T, General Electric, Mobil Oil, and McDonnell Douglas for whom I worked prior to and/or after entry my into the military. Each of these companies provided invaluable exposure and insight into private industry's practices to streamline costs and become more responsive to their customers while simultaneously focusing on their core businesses.

\section{Notes}

${ }^{1}$ Phillip A. Odeen, Transforming Defense - National Security in the $21^{\text {st }}$ Century, Report of the National Defense Panel, December 1997, 2.

${ }^{2}$ OASD Public Affairs News Release, "Defense Secretary Cohen Endorses Panel's Key Conclusion That Fundamental Infrastructure Reform is Essential to Transformation of U.S. Military,” 01 December 1997. 


\section{Abstract \\ Purpose/Problem Statement}

How does one identify which functions to outsource, why and to what degree? This paper hypothesizes that a decision support model tied to the Air Force Core Competencies, strategic environment, and objective criteria drawn from successful outsourcing activities may be the answer when oftentimes competing goals and objectives of the primary stakeholders is involved. The model supports the Air Force Program Manager (PM) in rapidly making the decision to outsource (or not) by providing a systematic approach that incorporates a hierarchical process and decision support tools, integrating the key stakeholders in the decision process, and providing flexibility to the program managers by allowing tailoring of the process and information to meet unique circumstances. Laying out some of the important factors that should be considered in planning to outsource a particular function, the model is descriptive rather that predictive.

\section{Research Method/Approach}

The data for this paper was compiled through research via the Internet, Air University Library, the General Accounting Office, Congressional Testimony from high ranking administration officials, and the study of lessons learned from the public and private sectors that have demonstrated success with outsourcing. A limited number of 
interviews were conducted to determine the extent to which practical support tools would be beneficial in making the determination to outsource.

\section{Preview of Methodology}

The ultimate objective of this paper is to put forth a tool (i.e., Model) that can be used to aid the PM in making a decision to outsource a particular function. The paper highlights those issues that will form the basis of the decision criteria within the model. It concludes with a detailed summary of the afore-to-mentioned criteria and uses a test case to demonstrate how the model would be used and to validate it. The test case to be used is the outsourcing of the National Launch Facilities at Vandenburg AFB, CA and Patrick AFB, FL.

The paper provides a brief definition of terms, limitations, and assumptions that drives the decision-making criterion within the model. Additionally, it clarifies the primary objectives outsourcing is targeting (i.e., cost avoidance and/or savings). After which, it explores the potential impediments to achieving these objectives. Finally, based on lessons learned from the public and private sectors, it develops criteria against which to assess whether a function should be outsourced. The model will be balanced among the Air Force Core Competencies, competing stakeholders' (i.e., Congress and DoD) goals and objectives, and strategic environment to ensure consistency with JV 2010. Finally, as stated above, the model will be applied to a decision that is pending within the Air Force, namely outsourcing the National Launch Ranges. 


\section{Chapter 1}

\section{Terms of Reference}

\section{Definition of Terms}

Varying definitions of outsourcing exist, but each has different fundamental assumptions regarding the role of the Government. As defined by the principal Air Force office responsible for outsourcing, it is "...the use of federal funds to pay a private company to do defense work or provide a service for a defense activity-no transfer of assets. An ultimate form of outsourcing is privatization which is the complete transfer of ownership and management of a function to the private sector, but DoD pays for the services associated with the function-includes the transfer of assets." 1 As one would expect, there are endless variants to these definitions; however, this paper adheres to these terms and will describe any variant during the discussion at hand.

\section{Assumptions}

This paper is based on several fundamental assumptions. The most significant assumptions are that the private sector can perform a function more efficiently than the Government, that a continual existence of a competitive marketplace exists, and that the projected savings can be realized. To accommodate competing national priorities (i.e., education, social welfare programs, etc) in an austere fiscal environment, significant 
growth in the DoD budget is unlikely and is virtually flat for the next six years, according to Air Force Chief of Staff, General Michael Ryan. ${ }^{2}$ Greater international instability (i.e., terrorism, information operations, and proliferation of weapons of mass destruction) and increased operational tempo will continue for the foreseeable future. ${ }^{3}$ Given the acquisition timelines for new weapon systems and the age of the current systems, maintenance will continue to be more costly than anticipated. ${ }^{4}$ To begin targeting these challenges and the increased maintenance costs, Secretary of Defense Cohen plans to "reengineer business practices, consolidate organizations to remove redundancy, encourage competition to reduce costs and improve quality, and eliminate excessive support structures." As an enabler that is the underpinning of all Air Force Core Competencies, Secretary Cohen's emphasis will allow the Air Force to sustain a force capable of meeting current threats to national security while still modernizing to meet the challenges of tomorrow. ${ }^{6}$

\section{Limitations of Data and Accompanying Analysis}

The General Accounting Office (GAO) has projected significant savings that can be achieved through outsourcing usually through a reduction in personnel; however little data exists which verifies the initial projections. In cases where data exists, accounting methods or lack of benchmarking does not easily facilitate the tracking of all pertinent costs in a manner that allows a comparison with private industry costs for equivalent

functions over time. ${ }^{7}$ Also, the projections made certain assumptions that may not be valid. It is questionable whether or not the competing goals and objectives of the stakeholders can be reconciled such that the savings can be achieved. ${ }^{8}$ Additionally, existence of a highly competitive commercial marketplace, the ability to accurate define 
the functions and performance metrics, and the relaxation of legislative obstacles are not necessarily achievable. ${ }^{9}$

\section{Notes}

1 Colonel Michael A. Collings, Chief, Air Force Office of Outsourcing and Privatization, Address to Air Force Association Symposium, Colorado Springs, CO, 24 May 1996.

2 Paul Proctor, “Outsourcing's Upside," Aviation Week \& Space Technology, Volume 148, Issue 18, 04 May 98, 13.

${ }^{3}$ OASD Public Affairs News Release, 01 December 1997.

${ }^{4}$ House, Defense Outsourcing, Challenges Facing DoD As It Attempts to Save Billions in Infrastructure Costs: Hearings before the Subcommittee on Readiness, Committee on National Security, (GAO Report, GAO/T-NSIAD-97-110, 12 March 1997), 11-14.

${ }^{5}$ OASD Public Affairs News Release, 01 December 1997.

${ }^{6}$ Honorable Arthur Money, Assistant Secretary of the Air Force (Acquisition), Keynote address to Air Force Association Symposium, Colorado Springs, CO, 24 May 1996.

${ }^{7}$ House, Defense Outsourcing, Challenges Facing DoD As It Attempts to Save Billions in Infrastructure Costs, 8.

${ }^{8}$ Senate, Defense Depot Maintenance, Uncertainties and Challenges DoD Faces in Restructuring Its Depot Maintenance Program: Hearings before the Subcommittee on Readiness, Committee on Armed Services, (GAO Report, GAO/T-NSIAD-97-112, 01 May 1997), 26.

${ }^{9}$ House, Defense Outsourcing, Challenges Facing DoD As It Attempts to Save Billions in Infrastructure Costs, 24. 


\section{Chapter 2}

\section{Background and Significance of Problem}

"Facing large shortfalls in its modernization accounts, DOD plans to reduce costs and generate savings for modernization through the outsourcing of support activities, ... costs can be reduced by $20 \%-40 \%$." 1

-General Accounting Office

\section{Air Force Budget History}

A glimpse of the Air Force budget offers a glimpse of the severity of the problem that outsourcing is intended to address and the model developed in this paper will facilitate. As of 1996, the budget has been reduced by nearly 50 percent over the last decade, from $\$ 120$ billion to $\$ 60$ billion. This budget has several competing accounts: military personnel, operations \& maintenance (O\&M), and investment (e.g., R\&D, acquisition). Currently, the O\&M account exceeds the investment account by several billion dollars (i.e., $\$ 22$ billion versus $\$ 19$ billion) which indicates the extent to which we are mortgaging our future to fund current operations. Additionally, from 1992 to 1996 as part of the overall military drawdown, the investment account has dropped from $\$ 30$ billion to $\$ 19$ billion. $^{2}$ Given the fact that the B52s are 34 years old, the F16s are 28 years old, C-5s are 25 years old, and it takes 5-7 years for new weapons systems to become fully operational, the imbalance between O\&M and investment accounts will only get worse. Not only is the investment account the source of modernization funds, 
but it is also the account for funding activities not initially forecast within the budget. For example in FY96, the Air Force had to unexpectedly reallocate from the investment account $\$ 900$ million for Bosnia and $\$ 80$ million for hurricane damage at Eglin AFB, FL. A decreasing or stagnate overall budget, requirements for O\&M of deployed forces, and previously unfunded activities exacerbate an existing problem with the investment account. Consequently, the model and accompanying process provides a systematic approach for outsourcing to provide the source of funds for modernization to meet the objectives of JV 2010. The key question then becomes is there evidence that outsourcing can reduce costs and free up funding? The succeeding two sections provides an unequivocal yes to this question, but with a caveat.

\section{Savings and Cost Avoidance via Outsourcing}

Whether one considers the DoD or private sectors, those functions that have been outsourced have fundamental features in common; the principal feature is the lure of savings or reduced cost of operations. Outsourcing is a booming business. According to the Outsource Institute, an internationally recognized research firm specializing in outsourcing, this market will grow to $\$ 318$ billion by 2001 - more than 300 percent above its 1996 total of $\$ 100$ billion. $^{3}$

Through detailed task analysis aimed at becoming more efficient, the private sector has concentrated on outsourcing functions that can be done more efficiently by others and has achieved remarkable success. Over 40 percent of the largest companies outsource a major piece of their operations. ${ }^{4}$ The total dollar amount outsourced by private companies per year amounts is $\$ 100$ billion, with savings of $10-15$ percent. ${ }^{5}$ 
At the same time private industry has taken up the challenge to reduce costs by becoming more efficient, the Air Force has done likewise. Over the past two decades the Air Force has seen savings ranging from 10-40 percent through outsourcing various support functions. In an effort to demonstrate its commitment, the DoD has institutionalized the issue of savings generated by outsourcing by including projected savings as part of their Program Objective Memorandum (POM). In fact, the Air Force has projected $\$ 1.2$ billion in savings from outsourcing in its 1998 POM. ${ }^{6}$ Even though there is evidence from both the private and public sector(s) that demonstrating savings can be achieved, the approach taken within DoD typically lacks the rigor and strategic focus, via JV 2010, tied to Air Force Core Competencies. The question that must be answered for planners is not only what should be outsourced, but also why? The model and accompanying process proposed in this paper provide the framework to address this question.

\section{Air Force Challenge}

In the current strategic environment (i.e., reductions in DoD spending and manpower, increased operational tempo, and increased reliance on military instrument of power) the Air Force has significant challenges. A principal challenge is consistency between strategy (i.e., means) and objectives (i.e., ends). A primary Air Force acquisition strategy is outsourcing functions that are not Air Force Core Competencies, inherently government, or can be performed more efficiently by the private sector. The objective of this strategy is increased efficiency that results in cost avoidance and/or savings. In implementing this strategy the Air Force must build the investment account while simultaneously balancing personnel, current O\&M, and core competencies as 
necessitated JV 2010. The significance of the successful implementation of outsourcing is paramount because it is the Air Force's primary strategy to solve the investment account shortfall. $^{7}$

\section{Notes}

${ }^{1}$ Senate, Defense Depot Maintenance, Uncertainties and Challenges DoD Faces in Restructuring Its Depot Maintenance Program, 26.

${ }^{2}$ Honorable Arthur Money, Assistant Secretary of the Air Force (Acquisition), 24 May 1996.

3 Charles E. Davis, CPA, Elizabeth B. Davis, CFP, and Lee Ann Moore, "Outsourcing Procurement Through Payables," Management Accounting: Official Magazine of the Institute of Management Accountants, Volume 80, Issue 1, July 1998, 38.

4 J. Michael Brower, "Outland: The Vogue of DoD Outsourcing and Privatization," Defense Acquisition University Journal, Acquisition Review Quarterly, Fall 1997, 383392.

${ }^{5}$ T. Lowry, USA Today, 25 March 1996, B1.

${ }^{6}$ Collings, Address at Air Force Symposium, 24 May 1996.

7 Honorable Arthur Money, Assistant Secretary of the Air Force (Acquisition), Keynote address to the Air Force Association Symposium, Colorado, Springs CO, 24 May 1996. 


\section{Chapter 3}

\section{Impediments to Embracing Outsourcing}

"Despite three and a half decades of studies and reforms, weapons cost too much, take too long to deploy, and do not perform as expected. Why is comprehensive change so elusive? " 1

Lauren Holland

\section{Human Nature}

Although the primary stakeholders (i.e., Congress and DoD) can be significant impediments to implementing the model and accompanying process discussed later in this paper, the fundamental building block of these institutions is people. Individual behavior and performance-albeit influenced by organizational, group, and personality characteristics-poses the most significant impediment to taking advantage of the potential increases in efficiency that outsourcing could provide. ${ }^{2}$ In order for the individual to want to learn (i.e., relatively permanent change in behavior that occurs as a result of experience reacting to an encountered situation) a new approach to doing business, one must first understand their motives. Motives can be either primary or secondary. Primary motives are unlearned or fixed and resistant to learning (i.e., pain avoidance, safety, power, and fear). Secondary motives, on the other hand, are learned and are adaptable and amenable to learning (i.e., achievement needs, specific job needs, and risk tolerance). ${ }^{3}$ Thus, at a very high level, one notices that primary and secondary 
motives are at play in each of the primary stakeholders. There are few strategies or models that can be used to satisfy the concerns of each unique individual stakeholder. Hence, the discussion of stakeholders that follows addresses the institutional impediments and the model discussed later in this paper considers the affects of these impediments when making the decision.

\section{Congress}

As an institution, Congress works at cross-purposes with its stated objective of allowing more outsourcing to reduce costs. Specifically, Title 10, U.S.Code Section 246 prevents the services from outsourcing to capable and reliable contractors more than 50 percent of mission-essential depot maintenance work. ${ }^{4}$ Also, Section 2461 requires use of A-76 Cost comparison data, notification of Congress of studies involving more than 45 civilians, and prohibits outsourcing of firefighters or security guards at military installations. The exemption of firefighters and security guards alone eliminated from consideration 25,900 people. $^{5}$ Additionally, Title 10, U.S.Code Section 2304 requires consideration be given to small and disadvantaged business for performing portions of the work on major weapons system. However, there is evidence that the Government incurs increased technical and administrative costs to integrate the components provided by the small or disadvantage business with the rest of the system. ${ }^{6}$

Also, Congress encourages DoD to adopt commercial business practices, but very often handcuffs them with restrictions in legislative language (i.e., strings to appropriations) that prevent achieving the desired affects or result in micro management of the acquisition organization. ${ }^{7}$ Further handcuffing of the DoD is seen in the manner in which funds are appropriated. By not providing funding stability through multi-year 
contracts, Congress undermines the stability of the entire program, which adds to its lifecycle cost. ${ }^{8}$ If there are electoral reasons for contradictory behavior, Congress often votes to continue programs which the DoD opposes for cost-benefit reasons (i.e., V-22 Osprey aircraft and SSN-21 Seawolf Submarines). ${ }^{9}$ Finally, from a democratic perspective Congress believes aggressive oversight as critical, even if efficiency is the casualty. It is perceived that only through oversight of DoD spending can Congress fulfill its responsibility as a steward of the taxpayers' trust. ${ }^{10}$ The legislative process appears to be driven not by predetermined, systematic, objective criteria but rather by a cumbersome, partisan debate that is devoid of any sense of adherence to a broader sense for the overall impact to the national security strategy. The measure of success becomes appealing to the broadest political constituency versus the best cost-benefit solution for the country. Consequently, Congressional oversight frequently politicizes the acquisition process and has the chilling effect of delaying major decisions that add costs to programs. It is the contention of this paper that success is achieved only by applying a systematic approach, considering the desired affects vs. actual affects of legislation, and integrating these factors in the decision-making process for outsourcing a function - all tied to strategic objectives.

\section{Department of Defense/Military Services}

In the same manner, senior DoD officials taunt the ability to save billions in infrastructure costs which could be reallocated to the investment account to fund system modernization. ${ }^{11}$ While on the other hand, the organization's key people are naturally resistant and lack the positive incentives to be the champions of change. ${ }^{12}$ To argue that those with a vested stake in the status quo have an incentive to transform the process is 
ignoring a fundamental factor that fuels behavior-fear. Whether it is fear of loss of control, power, prestige, or the unknown, this is a powerful human means of reinforcement—positively or negatively. ${ }^{13}$

Additionally, the culture within DoD equates the success of the program with completing the project—not improving the process. In this regard, cost estimating is a good point for discussion. The Program Manager (i.e., PM) is overly conservative in his cost estimates because he fears - rightly so - that any projected savings will be taken to fund a troubled program before savings materialize. The Air Force becomes progressively less conservative and holds the PM accountable for the next five years within the Planning, Programming and Budgeting System (PPBS) for these savings. ${ }^{14}$

While internal DoD studies indicate that outsourcing people intensive functions under omnibus contracts provides the greatest savings (i.e., 13 - 41 percent), the benefits are reduced by Deputy Secretary of Defense policy guidance to consider the affects on small businesses as part of the decision process. ${ }^{15}$ In a period of rapid technological change, the current acquisition process that was built on 50 years of Cold War tension is inherently reactive, bureaucratic and non-responsive. In future conflicts, which will probably be against unpredictable adversaries in unpredictable locations, we will not have the luxury of time that the current system demands. ${ }^{16}$ Therefore, increasing the quality of the decisions made while reducing the time to make them will become increasingly important in the acquisition of systems. The model and accompanying process in this paper specifically target this reality. 


\section{Notes}

${ }^{1}$ Lauren Holland, "The Weapons Acquisition Process-The Impediments to Radical Reform," Defense Acquisition University Journal, Acquisition Review Quarterly, Spring 1998, 236.

2 Andrew D. Szilagyi, Jr., and Marc J. Wallace, Jr.; Organizational Behavior and Performance, $4^{\text {th }}$ Edition; (Scott, Foresman and Company; Glenview, Illinois; 1987), 58.

${ }^{3}$ IBID, 51.

${ }^{4}$ Phillip A. Odeen, Transforming Defense-National Security in the $21^{\text {st }}$ Century, Report of the National Defense Panel, December 1997, 85.

${ }^{5}$ House, Report to the Chairman, Subcommittee on Military Readiness, Committee on National Security, Base Operations, Challenges Confronting DOD as It Renews Emphasis on Outsourcing: (GAO Report, GAO/NSIAD-97-86, March 1997), 18.

${ }^{6}$ Collings, Address at Air Force Symposium, 24 May 1996.

${ }^{7}$ Editorial, "Outsourcing No Place For Politics," Federal Computer Week, Editorial, 21 October 1996.

8 James S.B. Chew, "Commercial Best Practices," Defense Acquisition University Journal, Acquisition Review Quarterly, Spring 1997, 224.

${ }^{9}$ Holland, 241.

${ }^{10}$ IBID, 240.

${ }^{11}$ Money, Keynote address at Air Force Symposium, 24 May 1996.

12 Holland, 236-237.

${ }^{13}$ Szilagyi and Wallace, 50-52.

14 Odeen, 81.

${ }^{15}$ House, Report to the Chairman, Subcommittee on Military Readiness, 12.

${ }^{16}$ Odeen, 76. 


\section{Chapter 4}

\section{Characteristics and Lessons Learned}

"Descope the business, drop activities that do not sit easily with the prime activity, and concentrate on what fits its aptitudes." 1

—John Holt

Those functions outsourced by both the DoD and the private sector were uniquely similar (i.e., people intensive, outside of core competency). In each sector - albeit to varying degrees - outsourcing was preceded by a systematic approach tied to some desired outcome (i.e., increased efficiency). From a DoD perspective, efficiency translated into mission readiness to support JV 2010. Likewise from a private industry perspective, efficiency translated into increased global competitiveness. In both sectors, it is believed that this increased efficiency would result in significant cost savings that could be reapplied to the core business - building a better product for the customer.

\section{Department of Defense/Military Services}

Within the DoD, those functions most prone to outsourcing are those that are people intensive. Specifically, from 1978 through 1994 savings were achieved primarily through staff reductions. Additionally, the savings increased substantially as the number of positions involved in the activity increased. Within the Air Force, when fewer than 25 positions were involved, the savings averaged 13 percent. However, when the number of 
positions were over 300 , the savings averaged 41 percent. As an omnibus contract, the base support contract at Vance Air Force Base was able to achieve significant savings that would not have been possible using several contractors and in-house organizations. ${ }^{2}$

Other functions prone to outsourcing within DoD are those, which are inherently commercial and are typically base operating support functions. According to Office of Management and Budget (i.e., OMB) Circular Number A-76, there are 29 such functions ranging from advertising and public relations to transportation and management services. For a specific list of the OMB Circular A-76 base operations support functions, please refer to Appendix A. In FY1997 DoD had an active duty and civilian personnel strength of $2,319,000 .{ }^{3}$ Given the fact that it employed approximately 449,000 people combined active duty \& civilian - in these support functions, DoD estimates that these base support activities would cost more than $\$ 30$ billion in fiscal year $1997 .{ }^{4}$ If one applies the historical savings projections of 13 - 41 percent to the DoD projected costs for these functions the potential savings are substantial (i.e., $\$ 1.6$ billion to $\$ 3.9$ billion); hence, it is understandable why there is a great deal of focus on support functions.

The challenge that exists for the Air Force is to effect a smooth transition in the outsourcing process and in conjunction with DoD reach a consensus on definitions with GAO. ${ }^{5}$ Without a common definition, the principal stakeholders will continuously be at odds over the measures of success. Any transition must be managed such that it considers the affects on displaced Government workers, continues to support the mission, is done for the right reasons, and can be substantiated (i.e., efficiency, core competency, etc). An underlying concern that must also be addressed is the DoD rewards systems 
because champions for outsourcing must come from within the organization's hierarchy if it is going to become a reality.

\section{Private Industry}

In a similar manner, private industry has adopted a theme of a corporations in financial straits seeking to reduce costs: "descope the business, drop activities that do not sit easily with the prime activity, and concentrate on what best fits its aptitudes." ${ }^{6}$ The desire to reduce costs and concentrate on core competencies was borne out by a recent study that spanned the gambit of industries (i.e., agriculture, manufacturing, public accounting, construction, retail, and finance). The goal of 58 percent of those firms outsourcing was to reduce administrative costs. Of these firms seeking to reduce administration costs, 42 percent of them actually reduced costs by an average of 16 percent. Additionally, 34 percent outsourced so that they could concentrate on their core competencies; 44 percent actually were able to focus attention on core competencies. Not only were cost savings and ability to concentrate on core competencies driving motives for outsourcing, but access to state-of-the-art knowledge from specialty firms which maintained a highly trained staff that stayed abreast of the latest trends in technology was also critical. ${ }^{7}$

The push for efficiency is evident by the fact that companies are outsourcing to specialty firms that can perform functions more efficiently and hence reduce costs. Just recently Bell Atlantic outsourced its wireless towers to a specialty firm such that it could get out of the real estate and federal regulation business and as Vice President and Chief Financial Officer of Bell Atlantic Mobile, Dave Benson indicated "focus our resources on

our core business—our customers." ${ }^{8}$ Initially, companies outsource those functions that 
are oriented toward transaction processes and functions that are industry independent such as human resources functions (i.e., applicant screening, relocation, and benefits administration. Even in functions independent of industry, companies seek to reduce administration burdens, acquire specialized skills, and save time. ${ }^{9}$

\section{Lessons Learned}

Succinctly, the targets of opportunity for outsourcing are functions that are: labor intensive, industry independent, require access to state-of-the-art technology, require a great deal of time (i.e., cycle time drivers), don't fit within predefined Government-only functions or core competencies, and those that can be done more efficiently by another entity. As such the questions for analytical and deductive process (i.e., Appendix B)

considers these factors. A couple of issues require consideration as part of factoring these lessons learned into the model and accompanying decision-making process for outsourcing a particular function.

First, legislative restrictions (i.e., types of functions and quantities of people) and functions previously defined as uniquely Government should be re-examined. Once consensus is reach - albeit the hardest challenge - there should be relatively no objection from the principal stakeholders holding firm on this decision to outsource. Specifically, the issues of the degree congressional oversight, stewardship of the taxpayers trust, and maintaining Morale, Welfare, and Recreation (i.e., MWR) of members while deployed may require changes to the law of the land and hence pose obstacles. However, through a cooperative partnership among the principal stakeholders (i.e., Congress, DoD, DoC, Air Force, and industry), dialogue can produce results if there is a clear mandate tied to 
national security needs and consistent with long term national economic, diplomatic, and military budgetary constraints and priorities.

Second, only if activities/functions that possess national security implications can be firmly justified in an era of rapid proliferation of advanced technology should they remain uniquely Government. Again, effective dialogue can prevent this issue from becoming an obstacle. Although a significant user of key technologies, the federal Government is not the lead provider of this technology. Additionally, there is a worldwide information revolution making technology widely available to those willing to purchase it. Thus, we must carefully weigh giving up the benefits (i.e., savings) of using commercially available technology integrated into a military application (via outsourcing) versus the added cost of military unique technology and applications. After all, why should the Government spend a great deal of money hiding information or technology that is widely available from a multitude of sources? Finally, we must weight the impact to our domestic industry in a global economy resulting from these decisions.

\section{Notes}

${ }^{1}$ John Holt, “Commercializing Space," Space Policy, February 1997, 83.

${ }^{2}$ House, Report to the Chairman, Subcommittee on Military Readiness 8-12.

${ }^{3}$ House, Defense Outsourcing, Challenges Facing DoD As It Attempts to Save Billions in Infrastructure Costs, 10.

${ }^{4}$ House, Report to the Chairman, Subcommittee on Military Readiness, 3-4.

${ }^{5}$ IBID, 23-24.

${ }^{6}$ Holt, 83.

7 Celia J Renner, CPA and Darin Tebbe, CPA, "Who Is Outsourcing and Why," Management Accounting: Official Magazine of the Institute of Management Accountants, Volume 80, Issue 1, July 1998, 46.

8 Nicole Harris, "Crown to Run Bell Atlantic's Wireless Towers," Wall Street Journal-Eastern Edition, Volume 232, Issue 114, 10 December 1998, B5.

${ }^{9}$ Howard R. Mitchell, III, "A Moving Issue: To Outsource or Not To Outsource," Human Resource Magazine, Volume 43, Issue 5, May 1998, 59-60. 


\section{Chapter 5}

\section{Decision Support Model}

"Our present complex environment calls for a new logic - a new way to cope with the myriad of factors that affect the judgments we make and the decisions we draw. This approach should be justifiable, easy to apply and appeal to our good sense." 1

Thomas L. Saaty, Ph.D.

As mentioned at the outset, it was important to set the stage for why we must look to outsourcing to fund the vision of JV 2010 which assures that we can support National Security Objectives in a complex and uncertain future. As part of this journey, this paper described the shortfalls in the investment account and why they exist, impediments that affect the successful implementation of outsourcing, and characteristics/lessons learned from the public and private sectors. During this journey, this paper touched on those factors that should be considered as objective criteria to aid Air Force PMs make the decision to outsource a particular function. At this point, it brings it all together and demonstrates the utility of creating a model that increases the quality of decisions made while simultaneously reducing the time needed to make the decision.

\section{Why Is The Decision Support Model Significant?}

The model and accompanying process is an inclusive, systematic approach to determine what, when and why to outsource. It makes the decision-making process more 
objective by linking decisions directly to the strategic environment, national security policy, the Air Force Core Competencies, JV 2010, and lessons learned. Including principle stakeholders in the decision process is critical to achieving acceptance of any decisions made. Finally, incorporating these factors into the model increases the overall quality of decision made while still reducing the time required making the decision. Ultimately, the model would be used by the Air Force Program Manager to facilitate augmenting the investment account via cost avoidance and savings to support the objectives of JV 2010 in a budget-constrained environment.

\section{Description}

The model integrates an Analytic Hierarchy Process (AHP), a decision support tool (i.e., Expert Choice), and the factors developed throughout this paper that should drive the decision to outsource. An AHP is a powerful and flexible decision-making tool for making complex, multi-criteria problems that must consider both qualitative and quantitative issues. The AHP serves as a tool for assisting decision-makers formulate the important components of the decision into a hierarchical structure very similar to a tree. The AHP then reduces the complex decisions into a series of simple comparisons and rankings. Not only does the process drive to the best decision, but it also provides a clear rationale for the decision that was made. Expert Choice is a windows-based application that streamlines the process by automating it, integrating AHP into the decision support software, and using a user-friendly graphics interface because AHP forms the basis of Expert Choice's decision support software. A description of AHP and Expert Choice can be found in Appendix C. This paper highlighted those criteria based on National Security Objectives, JV 2010, Air Force Core Competencies, and lessons learned that should be 
considered in the decision-making process. By nature of the criteria that compose the model, this is a strategic decision. A description of each of the criterion and issues to be considered can be found in Appendix B. By integrating the date compiled using the framework in Appendices $\mathrm{B}$ and $\mathrm{D}$, the $\mathrm{PM}$ is able to relatively quickly make a determination of whether a function should be outsourced that can withstand scrutiny.

\section{Limitations}

This model should only be considered as part of a larger system. This larger system includes processes, procedures, and committed people trained in its use. There is a degree of subjectivity associated with the weighting and scoring of the respective criteria and factors that define the criteria. However, given the comprehensive, systematic approach taken and the decision support tool used to reach a decision, the influence of individual subjective inputs is minimized. The ultimate decision is based on how people actually think. Finally, the parameters that compose the model do not consider government intent not to outsource a particular function in an effort to subsidize US industry to ensure global competitiveness.

\section{Model Use}

The model is best used as part of a systematic approach using Expert Choice or a similar decision support tool that incorporates AHP. It is assumed that the initial decision criteria are valid. Additionally, the number of people performing the necessary tasks and the amount of time is set at the on-set of the activity; however, because consensus is required at various points in the process, the total number of people involved on a team 
should be minimized. Finally, a professional facilitator should be used to ensure adherence to the goals and objectives of the sessions.

There needs to be inclusion in the process of those most impacted by the decision to outsource the proposed function. To that end, although somewhat controversial, integration of contractor community representatives into the process would provide greater insight of the Government's intent. Thus, the results of each successive step would be briefed at a senior manager's forum of all those contractors who had expressed an interest to compete if the proposed function were outsourced. Likewise, members of the Congressional, Department of Defense, and Air Staffs would also be briefed on the process and the results of each successive step. It should be noted that these forums are for information purposes only and not decision forums. The only method to affect decisions is by representation on the teams that are open to representatives of each principal Government stakeholder. A description of the steps required to make the decision to outsource a proposed function based on the model can be found in Appendix D.

\section{Why Are The Process, Software, And Participants Significant?}

The process used is significant because it is systematic and ensures that the decision reached can be adequately defended (See Appendix D for detailed process steps). The input to the process is a thorough knowledge of the strategic environment surrounding the function to be outsourced by multi-disciplined teams that include functional and policy experts. Using Appendix B as a framework, these teams define the decision criteria, conduct individual ratings of the criteria, and document their results in a series of White Papers. A higher-level review team that includes principal stakeholders 
to ensure "buy in" reviews the White Papers, determines the relative importance (i.e., weights) of each of the criterion, and consolidates individual criterion scores and applies weights to arrive at a decision recommendation. Accordingly, the significance of the process is that it ensures quality input from knowledgeable people into a disciplined process with the prerequisite checks, balances, and insights from more senior members.

Following the necessary training on its application, each of the teams will be using the same Analytic Hierarchy Process (AHP) implemented into the software program Expert Choice. Expert Choice provides a windows-like interface to the AHP to provide a user friendly means of performing the peer-to-peer evaluations of the criteria. The software provides an output based on how people actually think when making decisions. Additionally, it provides the means to perform sensitivity analysis on the output. Specifically, it allows the decision-maker visibility into how changing weights of the individual criterion may impact the decision. Thus, the significance of this software application and accompanying process is that they provide a proven, structured approach to decision-making based on how people think in the real world which results in a higher quality decision.

The people involved are the most significant to the entire process. The initial input to the process must be performed by those that are knowledgeable not only in the function/system to be outsourced but also knowledgeable in the overall strategic direction of the military in general and the Air Force in particular. The various stakeholders (i.e., Congress, DoD Staff, and Contractors) need to be part of the decision process such that each has confidence in its rigor and objectivity. It is important to note that although these stakeholders will have visibility throughout the process, it is only through their respective 
representation on the higher-level review teams will they have input into the process. Finally, it is also important to note that the ultimate decision should reside with the acquisition organization Program Manager because he/she will be charged with the responsibility to execute the decision. Thus, the significance of incorporating functional and policy experts and stakeholders into the decision process is to ensure their visibility and "buy in", unity of effort among all players, and a more efficient and effective approach in determining whether a function should be outsourced.

\section{Notes}

${ }^{1}$ Expert Choice, Inc., Product Brochure, "www.expertchoice.com/eci/brochure." 


\section{Chapter 6}

\section{Model Test Case: National Launch Range}

\section{Description of Test Case}

The National Launch Ranges consist of the Government built launch facilities currently the responsibility of the 14 th Air Force. Under the command of the $30^{\text {th }}$ Space Wing, the Eastern Launch Range (ELR) is centered at Patrick AFB and Cape Canaveral Air Station on the east Florida coast. Under the command of the 45 Space Wing, the Western Launch Range (WLR) is centered at Vandenburg AFB, CA. These facilities are responsible for the launch and support of DoD and commercial satellites into equatorial and polar orbits respectively. Specifically, the test case is the outsourcing of these Launch Facilities and transitioning the Air Force to a tenant. It is not the concern of the model whether or not the function is outsourced to the private sector (i.e., contractors) or public sector (i.e., transfer to Federal Aviation Administration).

\section{Rationale for Selection}

There are several reasons why this function was considered as a test case. Over the next 10 years the private sector, which uses the WLR and ELR facilities, people, and modified processes, will surpass the Government in number of launches. Specifically, if one considers the projected number of satellites in the Teledesic, Iridium, and the 
Globalstar constellations, private industry is projected to launch nearly 400 satellites in the upcoming decade. ${ }^{1}$ During the same time frame the Government will launch onetenth that number of satellites. Given the preponderance of commercial launches, F. Whitten Peters, Acting Secretary of the Air Force, indicated that as the "minority user" costs for the launch infrastructure and its modernization must be shared with private industry based on the relative usage. ${ }^{2}$ If one considers the ongoing operations and maintenance cost, the reason for considering this function becomes more apparent. Specifically, in FY98, the Air Force budget for launch facilities and operations was approximately $\$ 520$ million. Additionally, the number of launch failures due to aging equipment has tripled in the past two years. ${ }^{3}$ This increased failure rate is a direct result of the afore-to-mentioned trend of transferring funds from the investment accounts to the O\&M accounts. Given the Government is the minority user, it is the contention of this paper that the Air Force should not use its limited investment and O\&M account to subsidize private industry when there are critical force shortfalls to which these resources could be committed. Additionally, given the relatively large number of Government people and the lessons learned from both the public and private sectors, outsourcing this function would also provide significant savings and a pool of skilled individuals with critical space-related talent that could be reallocated to support other Air Force activities (i.e., Expeditionary Aerospace Force (EAF) Concept).

\section{Model Recommendation}

To assess whether the launch ranges should be outsourced, one would apply the questions identified in Appendix B. This would provide an in-depth discussion in each of the primary criteria areas: Strategic Environment, Objective, Core Competencies, Joint 
Vision 2010, and miscellaneous issues. Each of these areas would drive production of a White Paper that is used as input to complete Appendix E. Additionally, if one considers the labor intensive nature of this function, its inherently commercial nature, private industry's greater proficiency due to number of launches per year, and the fact that outsourcing this function does not impact Air Force Core Competencies or mission satisfaction, one should strongly consider outsourcing this function. Finally, although difficult considering the number of inputs, Appendix F contains the score (i.e., 34.1) for the Launch Ranges. Based on this score and the Go/No-Go criteria, one should outsource the National Launch Ranges.

\section{Assessment of Model Results}

Use of the National Launch Ranges as a test case demonstrated the relative ease in using the model and accompanying process. Through Appendix B, the decision-maker has a framework that takes a strategic focus, reduces subjective aspects of the decisionmaking process, and provides valuable data that feeds the overall decision process. As such this step in the process is critical to success. Therefore, increasing the number of people and the disciplines involved may have impacted the results. Also, training on what Expert Choice can and can not do is likewise critical to understanding the results. Specifically, since it employs a linear model, the sensitivity analysis is limited to how changing the relative weight of one of the criterion might impact the decision. Finally, the results are consistent with the recommendations by the Scientific Advisory Board which indicated that in order to pay for change, the Air Force must get out of some mission areas, one of which was launch operations. ${ }^{4}$ 


\section{Notes}

1 Tom Breen, "Teledesic Turns to Motorola To Help Execute Ambitious Plan," Space Business News, 10 June 1998, 8.

${ }^{2}$ Tom Breen, “Air Force Wants Commercial Help In Effort to Modernize Launch Ranges," Space Business News, 10 June 1998, 4.

${ }^{3}$ Dr. John M. Borky, United States Air Force Scientific Advisory Board, Report on A Space Roadmap for the $21^{\text {st }}$ Century Aerospace Force, Volume 1, November 1998, 28.

${ }^{4}$ IBID, 28-29. 


\section{Chapter 7}

\section{Conclusions}

\section{Summary}

Over the last decade, the investment account has been raided to provide for ongoing O\&M and not previously planned or anticipated operations. In fact, as indicated earlier in this paper, the investment account has been cut by $50 \%$ within the last five years. With a level or decreasing share of the overall budget, the Air Force has a significant challenge to meet JV 2010 and national objectives. Throughout this discussion, I have discussed the severity of investment account shortfalls and the potential that outsourcing offers. The key question became is there evidence that outsourcing can reduce costs and free up the funding to support the investment account?

Using real world data, I demonstrated that significant savings have been realized in the private and public sectors. The limitation is that the functions outsourced have certain features in common. Succinctly, they are labor intensive, industry independent, and schedule drivers. Additionally, they don't fit within Government-only functions or Air Force Core Competencies and can be done more efficiently by another entity. Although I indicated that the savings are real, there are also challenges to realizing these savings. Institutional impediments on the part of Congress and DoD are the biggest 
challenges to overcome. Cooperation and inclusion in the decision processes for outsourcing functions is critical to overcoming these impediments.

\section{Relationship to Purpose/Problem Statement}

Determining what functions should be outsources requires a decision-making approach that is structured, systematic, and timely. Additionally, it requires a direct linkage to national, DoD, and Air Force objectives and a multi-disciplined set of skills that incorporates the inputs from the principal stakeholders throughout the process. The decision-making approach should be justifiable, easy to apply, and appeal to good common sense of the average person. Also, the decision reached from this approach should be able to withstand scrutiny. If these conditions were met, the Air Force Program Manager would finally have an effective tool that could ensure that the benefits of outsourcing selected functions would be achieved.

To improve the rigor and objectivity of the approach, the paper identified an approach which integrates a proven analytic process (i.e., AHP), a commercial product (i.e., Expert Choice), and criteria derived directly from the National Security Strategy, Joint Vision 2010, Air Force Core Competencies, and lessons learned from the public and private sectors. Because the approach also forges a partnership among the various stakeholders (i.e., Congress, DoD, and contractors) in the decision-making process and facilitates sensitivity analysis, it is able to withstand scrutiny. Finally, because the model incorporates both qualitative and quantitative aspects of the decision, it provides a decision based on how people actually think. Our future security demands high quality decisions be made on a timely basis. The model and accompanying process described within this paper provides the Air Force PM with a tool that answers "what, when and 
why to outsource." It provides a systematic, structured approach that increases the quality of decisions made by bringing the appropriate technical knowledge to bear on defining the problem, incorporating the key stakeholders into the decision process, and providing sensitivity analysis to verify the reasonableness of the decisions reached. Ultimately, the model and accompanying process will allow the Air Force PM a tool which is essential to providing the resources (i.e., cost avoidance and/or savings) to support the vision called forth in JV 2010 and meet the national objectives well into the next century. 


\section{Appendix A}

\section{Base Operating Support Functions}

OMB Circular Number A-76 identifies the following functions as those, which are

prime candidates for outsourcing: ${ }^{1}$

Natural Resource Services

Advertising and Public Relations

Financial and Payroll Services

Debt Collection

Bus Services

Laundry and Dry Cleaning

Custodial Services

Pest Management

Refuse Collection and Disposal Services

Food Services

Furniture Repair

Office Equipment Maintenance and Repair

Motor Vehicle Operation

Motor Vehicle Maintenance

Fire Prevention and Protection

Military Clothing

Guard Service

Electric Plants and Systems Operations and Maintenance

Heating Plants and System Operations and Maintenance

Water Plants and System Operations and Maintenance

Sewage and Waste Plants Operations and Maintenance

Air Conditioning and Refrigeration Plants

Other Utilities Operations and Maintenance

Supply Operations

Warehousing and Distribution of Publications

Transportation Management Services

Museum Operations

Contractor-Operated Parts Stores and Civil Engineering Supply Stores

Other Installation Services 


\section{Notes}

${ }^{1}$ House, Report to the Chairman, Subcommittee on Military Readiness, Appendix II. 


\section{Appendix B}

\section{Questions for Analytical and Deductive Process}

The questions are descriptive and should be used as suggestions of "how to think" not

"what to think" by the planner/analyst when considering outsourcing

\begin{tabular}{|c|c|}
\hline CRITERIA & ISSUES TO CONSIDER \\
\hline $\begin{array}{l}\text { I. STRATEGIC } \\
\text { ENVIRONMENT } \\
(25 \%)\end{array}$ & $\begin{array}{l}\text { References: A National Security Strategy for a New Century, } \\
\text { Applicable Presidential Decision Directive(s) Air Force } \\
\text { Doctrine Document 1, Joint Vision 2010, and Article 10, US } \\
\text { Code. }\end{array}$ \\
\hline a. Guidance. & $\begin{array}{l}\text { What guidance has higher authorities (i.e., HQ or the NCA) } \\
\text { given on outsourcing the proposed function? If specific } \\
\text { guidance is not available, what does the military planner } \\
\text { perceive as the national problem? }\end{array}$ \\
\hline b. Considerations. & $\begin{array}{l}\text { Why is consideration not being given to privatizing the } \\
\text { function? What is the long-term solution for the function? How } \\
\text { would costs be affected with the long term outsourcing of the } \\
\text { function? How would dual-use capability be handled? }\end{array}$ \\
\hline $\begin{array}{l}\text { c. DoD/Service } \\
\text { Issues. }\end{array}$ & $\begin{array}{l}\text { What is the DoD position on outsourcing the proposed } \\
\text { function? What are the operational ramifications for the } \\
\text { combatant commanders? What are the ramifications within the } \\
\text { Planning, Programming and Budgeting System (PPBS)? How } \\
\text { will "color of money" issues affect outsourcing the proposed } \\
\text { function? To what extent may other services benefit from } \\
\text { following a similar course? }\end{array}$ \\
\hline d. Security Issues. & $\begin{array}{l}\text { What critical technology may be released to the open market? } \\
\text { What other avenues are available for the proliferation of the } \\
\text { same information? Is the risk or proliferation manageable, } \\
\text { considering the relative cost of protection? }\end{array}$ \\
\hline $\begin{array}{l}\text { e. Legislative } \\
\text { Issues. }\end{array}$ & $\begin{array}{l}\text { How may Article } 10 \text { of the US Code be affected? What is the } \\
\text { GAO's position on outsourcing the proposed function? To } \\
\text { what extent has discussion on the affected areas already begun } \\
\text { based on other initiatives? What is the plan to get the } \\
\text { appropriate Congressional committee on board? }\end{array}$ \\
\hline
\end{tabular}




\begin{tabular}{|c|c|}
\hline f. Industrial Base. & $\begin{array}{l}\text { To what extent does viable competition for the proposed } \\
\text { function exist? Would a monopoly result from the long term } \\
\text { outsourcing of a function? What is the potential impact to US } \\
\text { industry global competitiveness if repackaging dual-use } \\
\text { technology were prohibited? What history do we have within } \\
\text { the private and public sectors that demonstrates there is value to } \\
\text { be gained by outsourcing the proposed function? }\end{array}$ \\
\hline $\begin{array}{l}\text { II. OBJECTIVE } \\
(20 \%)\end{array}$ & $\begin{array}{l}\text { Reference: Program Director Guidance and Scientific Advisory } \\
\text { Board Report on A Space Roadmap for the } 21^{\text {st }} \text { Century } \\
\text { Aerospace Force, November } 1998\end{array}$ \\
\hline $\begin{array}{l}\text { a. Program } \\
\text { Director's Intent }\end{array}$ & $\begin{array}{l}\text { What is the objective (i.e., efficiency, savings, greater focus) of } \\
\text { outsourcing the function? Who is the decision-maker(s)? To } \\
\text { what extent have you coordinated with those who may be } \\
\text { affected by outsourcing the function? What can outsourcing } \\
\text { provide that the current strategy does not? }\end{array}$ \\
\hline $\begin{array}{l}\text { b. Measure of } \\
\text { Effectiveness }\end{array}$ & $\begin{array}{l}\text { How are you going to measure success? What aspects of the } \\
\text { process require benchmarking? What conditions must be met to } \\
\text { achieve the objective? To what extent are these conditions } \\
\text { within the control of the primary decision-maker(s)? }\end{array}$ \\
\hline c. Risk & $\begin{array}{l}\text { To what extent has outsourcing the proposed function injected } \\
\text { additional cost, schedule, or performance risk to the overall } \\
\text { system? How is the integration of the outsourced function and } \\
\text { its operations into the larger system going to be } \\
\text { accommodated? }\end{array}$ \\
\hline $\begin{array}{l}\text { III. AIR FORCE } \\
\text { CORE } \\
\text { COMPETENCIES } \\
(15 \%)\end{array}$ & Reference: Air Force Doctrine Document 1, September 1997. \\
\hline a. Foundation. & $\begin{array}{l}\text { What impact will the outsourcing of the proposed function have } \\
\text { on the people currently performing the function? What impact } \\
\text { will outsourcing the proposed function have on the } \\
\text { organization? What process will be used to mitigate these } \\
\text { impacts? How will outsourcing the proposed function allow } \\
\text { greater focus on Core Competencies or enhance the attainment } \\
\text { of the Core Competencies? }\end{array}$ \\
\hline
\end{tabular}




\begin{tabular}{|c|c|}
\hline $\begin{array}{l}\text { b. Air \& Space } \\
\text { Superiority. }\end{array}$ & $\begin{array}{l}\text { What aspects of the outsourced function are critical to achieve } \\
\text { air and space superiority? How does outsourcing it enhance the } \\
\text { combatant commander's ability to achieve air and space } \\
\text { superiority? What are the risks, limitations and restrictions that } \\
\text { might be introduced to the combatant commander due to } \\
\text { outsourcing the proposed function? }\end{array}$ \\
\hline $\begin{array}{l}\text { c. Precision } \\
\text { Engagement. }\end{array}$ & $\begin{array}{l}\text { What aspects of the outsourced function are critical to support } \\
\text { precision engagement? How does outsourcing it enhance the } \\
\text { combatant commander's ability to apply technology and } \\
\text { techniques of precision engagement at any point on the globe } \\
\text { when required? What are the risks, limitations and restrictions } \\
\text { that might be introduced to the combatant commander due to } \\
\text { outsourcing the proposed function? }\end{array}$ \\
\hline $\begin{array}{l}\text { d. Information } \\
\text { Superiority. }\end{array}$ & $\begin{array}{l}\text { What aspects of the outsourced function are critical to support } \\
\text { information superiority? How does outsourcing it enhance the } \\
\text { combatant commander's ability to collect, control, exploit, and } \\
\text { defend information while denying the adversary the same. What } \\
\text { are the risks, limitations and restrictions that might be } \\
\text { introduced to the combatant commander due to outsourcing the } \\
\text { proposed function? }\end{array}$ \\
\hline e. Global Attack. & $\begin{array}{l}\text { What aspects of the outsourced function are critical to support } \\
\text { global attack? How does outsourcing it enhance the combatant } \\
\text { commander's ability to rapidly and persistently apply decisive } \\
\text { air power at any point on the globe when required? What are } \\
\text { the risks, limitations and restrictions that might be introduced to } \\
\text { the combatant commander due to outsourcing the proposed } \\
\text { function? }\end{array}$ \\
\hline $\begin{array}{l}\text { f. Rapid Glob } \\
\text { Mobility. }\end{array}$ & $\begin{array}{l}\text { What aspects of the outsourced function are critical to support } \\
\text { rapid global mobility? How does outsourcing it enhance the } \\
\text { combatant commander's ability to project air power at any } \\
\text { point on the globe when required? What are the risks, } \\
\text { limitations and restrictions that might be introduced to the } \\
\text { combatant commander due to outsourcing the proposed } \\
\text { function? }\end{array}$ \\
\hline $\begin{array}{l}\text { g. Agile Comb } \\
\text { Support. }\end{array}$ & $\begin{array}{l}\text { What aspects of the outsourced function are critical for agile } \\
\text { combat support? How does outsourcing it enhance the } \\
\text { combatant commander's ability to reduce cycle times and } \\
\text { provide greater visibility into logistic support? What are the } \\
\text { risks, limitations and restrictions that might be introduced to the } \\
\text { combatant commander due to outsourcing the proposed } \\
\text { function? }\end{array}$ \\
\hline $\begin{array}{l}\text { IV. JOINT } \\
\text { VISION } 2010 \\
(30 \%)\end{array}$ & $\begin{array}{l}\text { Reference: "Joint Vision 2010, America's Military: Preparing } \\
\text { For Tomorrow" - General John M. Shalikashvili, Chairman of } \\
\text { the Joint Chiefs of Staff, } 1996 .\end{array}$ \\
\hline
\end{tabular}




\begin{tabular}{|l|l|}
\hline a. Foundation. & $\begin{array}{l}\text { What impact does outsourcing the proposed function have on } \\
\text { service men and women? How was the reserve and guard } \\
\text { factored into the decision to outsource the proposed the propose } \\
\text { function? How is training and readiness improved by } \\
\text { outsourcing the proposed function? What impact does } \\
\text { outsourcing the proposed function have on leadership } \\
\text { development? What impact does outsourcing the proposed } \\
\text { function have on fielding technologically superior systems? }\end{array}$ \\
\hline \begin{tabular}{l|l|} 
b. Dominant \\
Maneuver.
\end{tabular} & $\begin{array}{l}\text { How does outsourcing the proposed function aid in controlling } \\
\text { breadth, depth, and height of battlespace? How does } \\
\text { outsourcing the proposed function facilitate sustained and } \\
\text { synchronized operations from dispersed locations? }\end{array}$ \\
\hline Engagement. & $\begin{array}{l}\text { How does outsourcing the serve as an enabler to enhance the } \\
\text { ability to locate, identify, track, engage delivering the desired } \\
\text { effects, assess success, and re-engage with precision if required. }\end{array}$ \\
To what extent is the "system of systems" concept impacted by \\
outsourcing? To what extent is commonality among US forces \\
and potential allies affected?
\end{tabular}




\begin{tabular}{|c|c|}
\hline $\begin{array}{ll}\text { c. Internal } & \text { (To } \\
\text { Program) } & \\
\text { Impediments } & \end{array}$ & $\begin{array}{l}\text { What are the potential obstacles to implementing the proposed } \\
\text { strategy? Who are the affected parties and how will you get } \\
\text { them on board? How will decisions be made to deal with } \\
\text { impediments? What support would be required from senior HQ } \\
\text { to facilitate resolution? }\end{array}$ \\
\hline $\begin{array}{l}\text { d. External (To } \\
\text { Program) } \\
\text { Impediments }\end{array}$ & $\begin{array}{l}\text { What are the potential obstacles to implementing the proposed } \\
\text { strategy? Who are the stakeholders and how will you get them } \\
\text { on board? How will decisions be made to deal with } \\
\text { impediments? What support would be required from senior HQ } \\
\text { or other agencies to facilitate resolution? }\end{array}$ \\
\hline
\end{tabular}

Continue to formulate. Ask these types of questions, develop sources, collect information, and determine the relative significance. This process must be continually updated. In time most information is refined and clarified. Your analysis will become more accurate and focused.

Once answered, these questions form the basis of a series of White Papers that are used to complete the decision process (i.e., Appendix D). 


\section{Appendix C}

\section{Control, Logic, Structure, and Efficiency ${ }^{1}$}

\section{Users and Uses}

AHP and Expert Choice is currently used by:

Boeing

$3 \mathrm{M}$

Xerox

Exxon

The World Bank

IBM

GE

AT\&T

Rockwell International

Citibank

NASA

The Department of Defense

The Wharton School

Harvard University

Dartmouth University

Allstate Insurance

Amoco

Alcoa

Anderson Consulting

Deloitte \& Touche
In a broad range of areas, including:

Benefit/Cost analysis

Resource allocation

Risk analysis

Strategic planning

Performance evaluation

Environmental decision-making

TQM/Business re-engineering

Negotiation \& conflict resolution

Project management

Marketing decisions

Acquisition/Merger evaluation

Product development

Site selection or relocation

What-if forecasting

The software and process is used by these organizations to bring together knowledge and expertise from multiple sources to improve the decision-making process to attack critical business areas.

\section{Notes}

${ }^{1}$ Expert Choice, Inc., Product Brochure, “www.expertchoice.com/eci/brochure.” 


\section{The Process and the Support Tool}

\section{Analytic Hierarchy Process (AHP) ${ }^{1}$}

The Analytic Hierarchy Process, which forms the basis of Expert Choice decision support software, enhances decision-making by providing a logical, easy-to-use framework in which all the elements of a decision can be defined, organized and carefully evaluated. Designed to reflect the way people actually think, the AHP was developed more than 20 years ago and continues to be the most highly regarded and widely used decision-making theory in use.

With the AHP, your objectives, alternatives and criteria are arranged in a hierarchical structure similar to a family tree. The process of building this structure not only helps you identify all the elements of your decision more accurately, but also to recognize the interrelationships between them.

Among the factors that make the AHP the world's most popular decision support theory, is that it accommodates hard data—such as costs, interest rates and dimensionsas well as personal judgment and intuition. It also permits you to derive relative, mathematically based weights for your criteria, instead of having to guess or randomly assign weights to variables, as other decision analysis techniques do.

By reducing complex decisions to a series of simple comparisons and rankings, then synthesizing the results, the AHP not only helps you arrive at the best decision, but also provides a clear rationale for the choice you made. 


\section{Team Expert Choice Software ${ }^{2}$}

TeamEC for windows is a decision-support software tool designed specifically to help groups enhance the quality of their decisions by bringing structure to their decisionmaking process. Based on the Analytic Hierarchy Process (AHP) decision-making methodology, TeamEC helps group members define the objectives, goals, criteria and alternatives and then organize them into a hierarchical structure. Using hand-held radio controlled keypads for voting, participants compare and prioritize the relative importance of the decision variables. TeamEC then synthesizes the groups' judgments to arrive at a conclusion by aggregating individual judgments or priorities. It further allows you to perform sensitivity analysis on the results to determine how changing the weights of individual criterion will affect the outcome of the decision.

\section{Notes}

${ }^{1}$ Expert Choice, Inc., Product Brochure, "www.expertchoice.com/eci/brochure."

${ }^{2}$ Expert Choice, Inc., Product Brochure, "www.expertchoice.com/eci/software." 


\section{Appendix D}

\section{Process Execution Steps}

\section{Step 1: Reach Common Understanding}

Input: Individuals with domain-specific knowledge and a working knowledge of JV 2010 and the Air Force Core Competencies

(1) Establish Teams (i.e., Team 1a, Team 1b, Team 1c, Team 1d, etc) to develop white paper(s) to refine each criterion within Appendix B using the thoughts provided.

- To expedite completion of this step and to better focus resources, separate teams may be used for each criterion white paper.

- $\quad$ The number of people per team should be limited to three to five people to enhance efficiency without sacrificing quality.

(2) Obtain team consensus on definitions.

(3) Obtain decision-maker concurrence.

Output: Approved definitions of criteria

\section{Step 2: Determine Criterion Weights}

Input: White papers defining criterion from Step 1

(1) Establish Teams (i.e., Team 2a, Team 2b, Team 2c, Team 2d, etc) to review definitions of each criterion using White Papers. 
- The team membership does not need to be the same as Step 1. However, the lead for each Team from Step 1 must be included as actual Team members within this step or on call as advisors.

- Additionally, this Team should include representation from those Government organizations affected by the decision to outsource the proposed function.

- Finally, the number of people should range between nine to thirteen people and should more senior than those from Step 1. Using more than thirteen people would complicate the consensus process.

(2) Train Team 2 on the use of the decision-support tool, Expert Choice.

(3) Using Expert Choice, perform peer-to-peer ratings to establish the relative importance (i.e., weights) of the criteria and provide the means to perform the sensitivity analysis after the final evaluation.

(4) Brief the process used and results to the decision-maker(s) forum for concurrence.

- The forum in which the results are briefed should include the senior of those represented on the team that might be affected by the decision to outsource the proposed function.

- It should be noted that approval can't be achieved due to the nature of the dynamics associated with the use of the tool.

Output: Weights for each criterion

\section{Step 3: Score Each Criterion}

Input: White Paper(s) defining criterion from Step 1

(1) Reconvene Team 1 to conduct the individual ratings of the criterion.

(2) Train Team 1a, Team 1b, Team 1c, Team 1d, etc. on the use of the decision-support tool, Expert Choice.

(3) Using Expert Choice, establish the score for each criterion. This may be done immediately following Step 1 because Team 1 members do not need the actual weights of the criteria to perform their function.

(4) Update the White Paper(s) to include the results of the team scoring.

Output: Score for each criterion 


\section{Step 4: Make Recommendation}

Input: Updated White Paper(s) from Step 3

(1) Team 2 reconvenes to review updated White Paper(s). Team 1 membership needs to be available to answer any potential questions or concerns.

(2) Team 2 consolidates individual criteria scores and applies appropriate weights.

(3) Team 2 conducts sensitivity analysis based on the initial criteria weights, i.e., how would the decision change based on different weights.

(4) Team 2 provides recommendation to decision maker(s) forum.

Output: Recommendation 


\section{Appendix E}

\section{Assessment Matrix (Generic)}

CANDIDATE ROLE/MISSION/FUNCTION:

RATING SCALE (PLACE "X" IN APPROPRIATE COLUMN FOR EACH ROW)

\section{DECISION CRITERIA}

CHARACTERIZATION OF FUNCTION

- Total People Involved

- DoD Civilians Positions Affected

- Rapid Technology Growth

- Inherently Government

- Inherently Commercial

- Benchmarking Completed

- Leverage With Other Gov't Agencies

- Outscourcing Development Only

- Outscourcing Development \& O\&M

- Does Viable Competition Exist

$\begin{array}{cccccccccc} & 6 & 20 & 76 & 100 & 150 & & 250 & 201 & \\ \text { Fewer } & \text { to } & \text { to } & \text { to } & \text { to } & \text { to } & 201 \text { to } & \text { to } & \text { to } & \text { More } \\ \text { Than 5 } & 19 & 75 & 99 & 149 & 199 & 249 & 300 & 350 & \text { Than 350 }\end{array}$

Summary Rationale

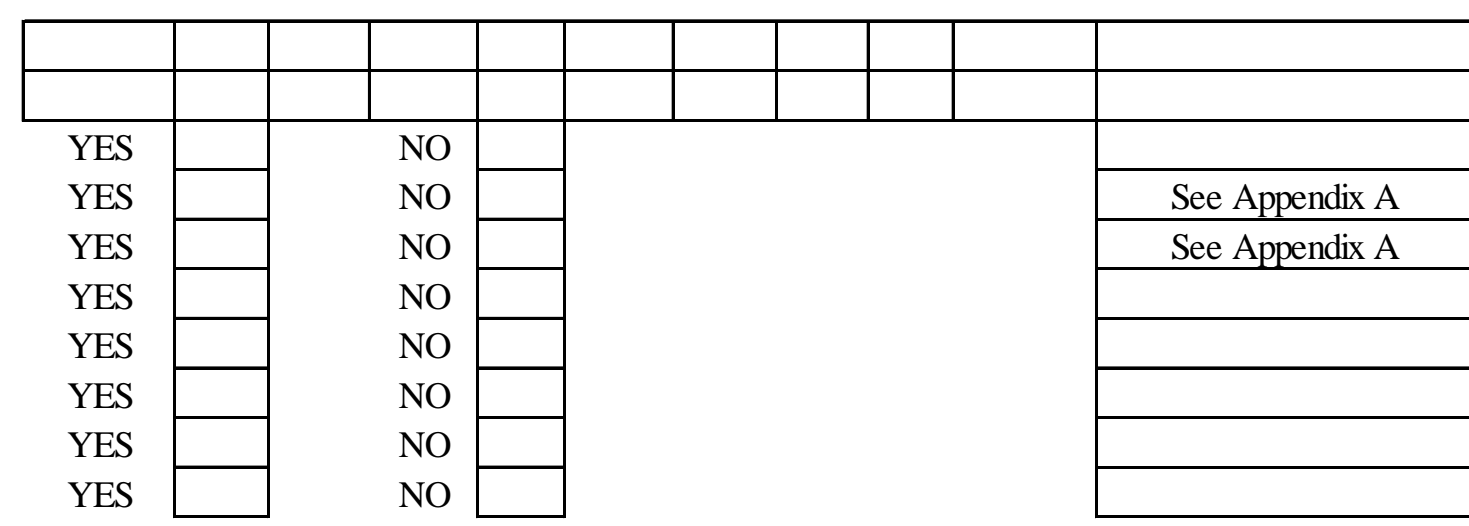


RATINGSCALE(PLACE "X" IN APPROPRIATECOLUMNFOREACHROW)

\section{DECISION CRITERIA}

I. STRATEGICENYRONMENT

- Consistency with HQ Policy

- Affect on:

-- Long TermSupport

- Operations

-- PPBS

- Leverage with Other Agencies

- Critical Technology

-- Encryption/Decryption

-- WMD

-- Low Observables/Stealth

-- Information Management

-- Synthetic Apertur Radar

-- Hyper/Ultra spectral

-- Communications

-- Supercomputing

-- Other

- Congress

-- Article 10 Impacts

-- GAO Position(s)

- Industrial Base

- Consistent with Trends

--Global Competitiveness

Score $($ Higher is Better $)=$

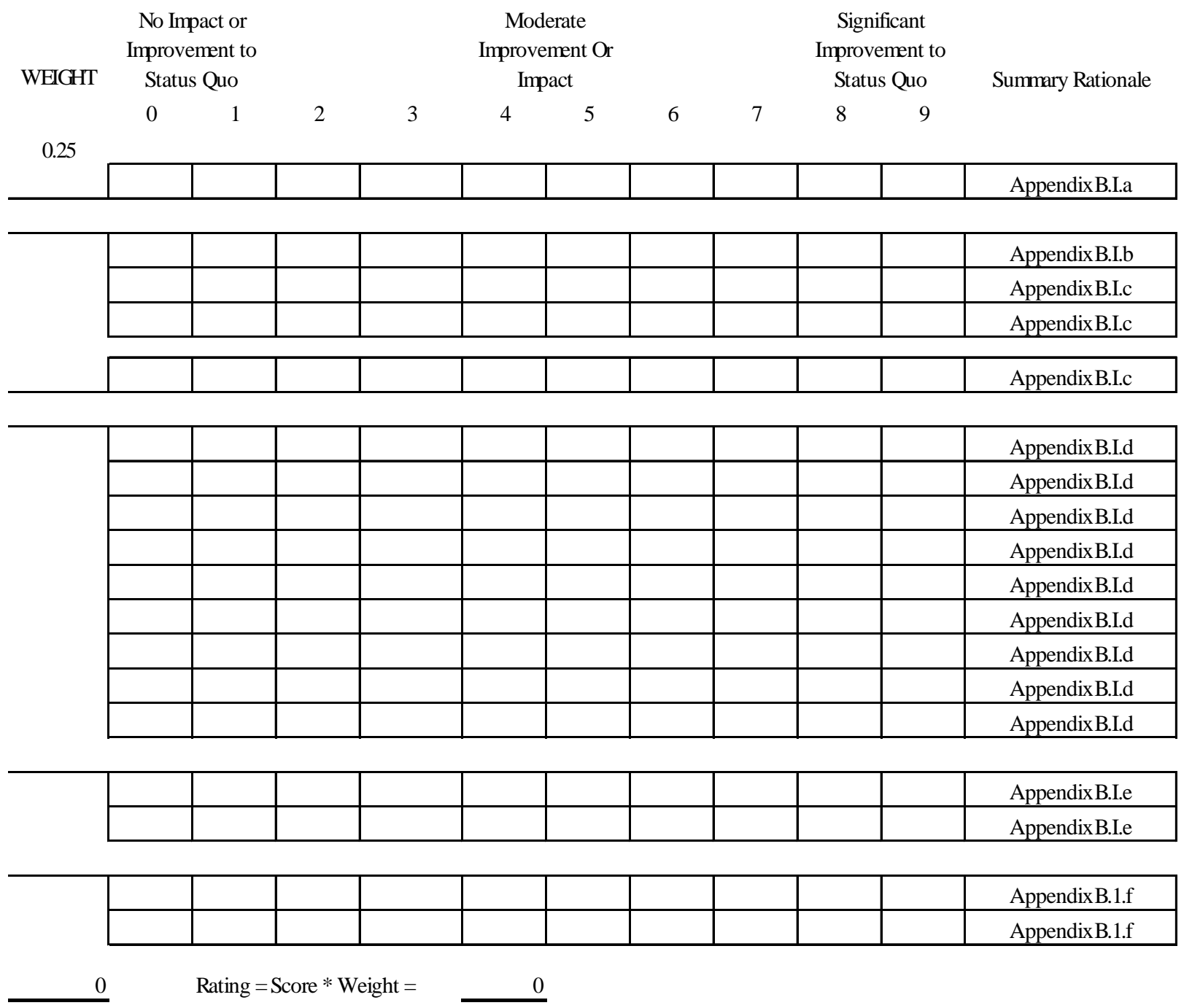


CANDIDATE ROLE/MISSION/FUNCTION:

RATING SCALE (PLACE "X" IN APPROPRIATE COLUMN FOR EACH ROW)

\begin{tabular}{|c|c|c|c|c|c|c|c|c|c|c|c|c|}
\hline \multirow[t]{2}{*}{ DECISION CRITERIA } & \multicolumn{3}{|c|}{$\begin{array}{l}\text { No Impact or } \\
\text { Improvement to } \\
\text { Status Quo }\end{array}$} & \multicolumn{5}{|c|}{$\begin{array}{c}\text { Moderate } \\
\text { Improvement Or } \\
\text { Impact }\end{array}$} & \multicolumn{3}{|c|}{$\begin{array}{c}\text { Significant } \\
\text { Improvement to } \\
\text { Status Quo }\end{array}$} & \multirow[t]{2}{*}{ Summary Rationale } \\
\hline & & 0 & 1 & 2 & 3 & 4 & 5 & 6 & 7 & 8 & 9 & \\
\hline CTIVE & 0.20 & & & & & & & & & & & \\
\hline aking Autl & & & & & & & & & & & & Appendix B.II.a \\
\hline
\end{tabular}

- Effectiveness

-- Efficiency

-- Greater Focus On Core

-- Cost Savings

\begin{tabular}{|l|l|l|l|l|l|l|l|l|l|l|}
\hline & & & & & & & & & & Appendix B.II.b \\
\hline & & & & & & & & & & Appendix B.II.b \\
\hline & & & & & & & & & & Appendix B.II.b \\
\hline
\end{tabular}

\section{Risk \\ -- Cost \\ -- Schedule \\ -- Performance \\ -- Integration}

\begin{tabular}{|l|l|l|l|l|l|l|l|l|l|l|}
\hline & & & & & & & & & & Appendix B.II.c \\
\hline & & & & & & & & & & Appendix B.II.c \\
\hline & & & & & & & & & & Appendix B.II.c \\
\hline
\end{tabular}

Score $($ Higher is Better $)=$

Rating $=$ Score $*$ Weight $=$ 0 
CANDIDATE ROLE/MISSION/FUNCTION:

RATING SCALE (PLACE "X" IN APPROPRIATE COLUMN FOR EACH ROW)

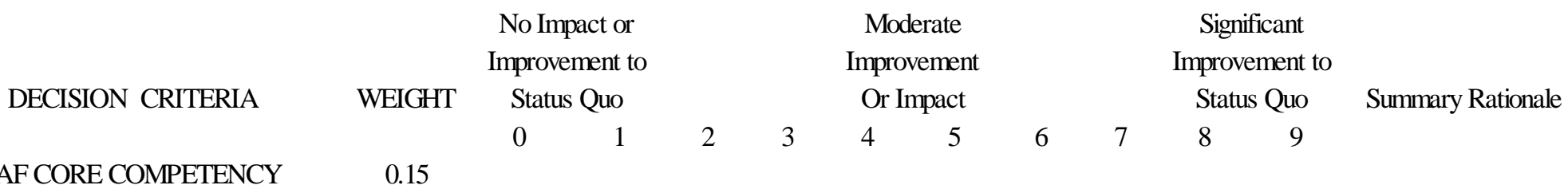

- People \& Organization

\begin{tabular}{c}
\begin{tabular}{c|c|c|c|c|c|c|c|c|c|c|}
\hline & & & & & & & & & & Appendix B.III.a \\
\hline
\end{tabular} \\
\hline
\end{tabular}

- Air \& Space Superiority

- Precision Engagement

\begin{tabular}{c|c|c|c|c|c|c|c|c|c|c|}
\hline & & & & & & & & & & Appendix B.III.c \\
\hline
\end{tabular}

- Info Superiority

- Global Attack

\begin{tabular}{c}
\begin{tabular}{c|c|c|c|c|c|c|c|c|c|c|}
\hline & & & & & & & & & & Appendix B.III.e \\
\hline & & & & & & & & & & Appendix B.III.f \\
\hline
\end{tabular} \\
\hline
\end{tabular}

Score $($ Higher is Better $)=$

0

Rating $=$ Score $*$ Weight $=\quad-\quad 0$ 


\section{RATING SCALE (PLACE "X" IN APPROPRIATE COLUMN FOR EACH}

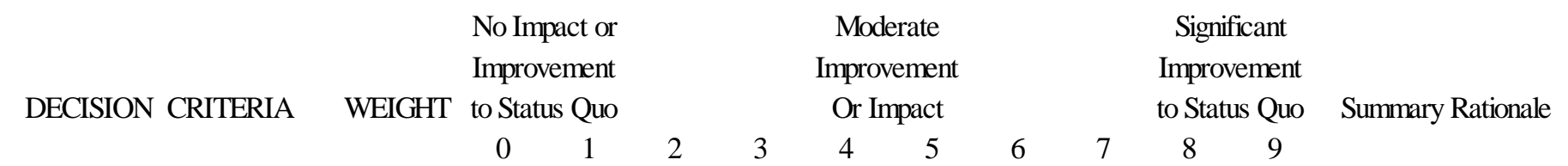

IV. JOINT VISION $2010 \quad 0.30$

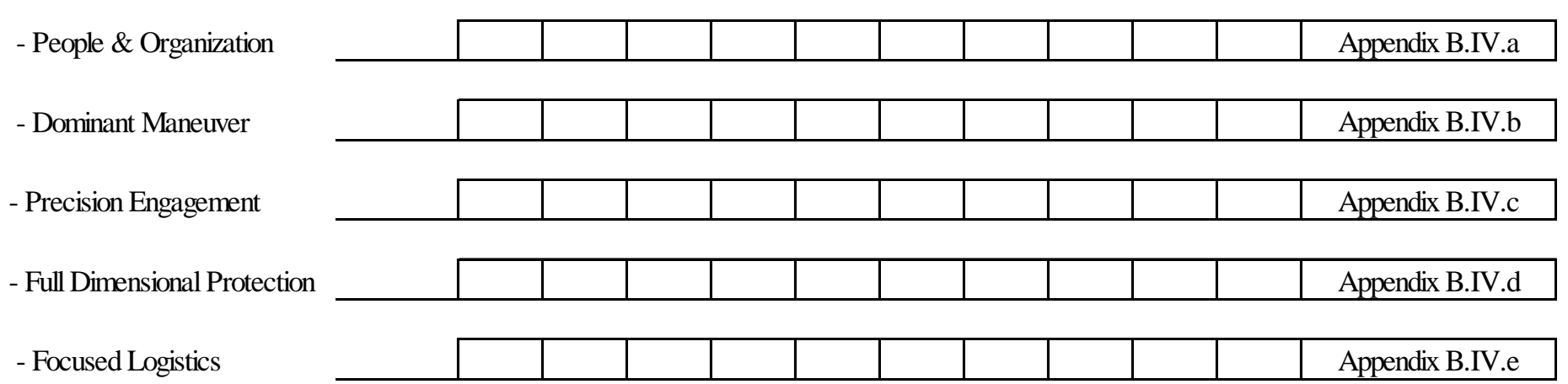

Score $($ Higher is Better $)=\quad$ Rating $=$ Score $*$ Weight $=\quad 0$ 


\section{RATING SCALE (PLACE "X" IN APPROPRIATE COLUMN FOR EACH}

\begin{tabular}{|c|c|c|c|c|c|c|c|c|c|c|c|c|}
\hline \multirow[t]{2}{*}{ DECISION CRITERIA } & \multicolumn{3}{|c|}{$\begin{array}{r}\text { No Impact or } \\
\text { Improvement } \\
\text { WEIGHT to Status Quo }\end{array}$} & \multicolumn{4}{|c|}{$\begin{array}{l}\text { Moderate } \\
\text { Improvement } \\
\text { Or Impact }\end{array}$} & \multicolumn{4}{|c|}{$\begin{array}{l}\text { Significant } \\
\text { Improvement } \\
\text { to Status Quo }\end{array}$} & \multirow[t]{2}{*}{ Summary Rationale } \\
\hline & & 0 & 1 & 2 & 3 & 4 & 5 & 6 & 7 & 8 & 9 & \\
\hline V. MISCELLANEOUS & 0.10 & & & & & & & & & & & \\
\hline - Culture & & & & & & & & & & & & Appendix B.V.a \\
\hline - Organization & & & & & & & & & & & & Appendix B.V.b \\
\hline - Overcoming Internal Impedi & & & & & & & & & & & & Appendix B.V.c \\
\hline - Overcoming External Imped & & & & & & & & & & & & Appendix B.V.d \\
\hline
\end{tabular}

Score $($ Higher is Better $)=\quad$ Rating $=$ Score $*$ Weight $=\quad 0$ 
CANDIDATE ROLE/MISSION/FUNCTION:

\section{DETERMINATION}

GO (I.E. PROCEED WITH OUTSOURCING)

STUDY FURTHER (I.E. INVESTIGATE FURTHER)

STOP (I.E. DO NOT OUTSOURCE FUNCTION)
$6 \leq$ RATING 9

$4 \leq$ RATING 6

$0 \quad<$ RATING 4

\section{DECISION FACTOR}

I. STRATEGIC ENVIRONMENT

II. OBJECTIVE

III. AIR FORCE CORE COMPETENCIES

IV. JOINT VISION 2010

V. MISCELLANEOUS

TOTAL

DECISION

\begin{tabular}{|c|c|c|c|c|c|}
\hline \multirow[b]{2}{*}{ WEIGHT } & \multirow[b]{2}{*}{ SCORE } & \multirow[b]{2}{*}{ RATING } & \multicolumn{3}{|c|}{ NOTES } \\
\hline & & & STOP & STUDYFURTHER & $\mathrm{GO}$ \\
\hline 0.25 & 0 & 0 & Rating $<6$ & $6<$ Rating $<9$ & $9<$ Rating $<1$ \\
\hline 0.20 & 0 & 0 & Rating $<2.4$ & $2.4<$ Rating $<3.6$ & $3.6<$ Rating $<5$ \\
\hline 0.15 & 0 & 0 & Rating $<4.2$ & $4.2<$ Rating $<6.3$ & $6.3<$ Rating $<7$ \\
\hline 0.30 & 0 & 0 & Rating $<6$ & $6<$ Rating $<9$ & $9<$ Rating $<13$ \\
\hline 0.10 & 0 & 0 & Rating $<1.6$ & $1.6<$ Rating $<2.4$ & $2.4<$ Rating $<3$ \\
\hline 1.00 & 0 & 0 & Rating $<20.2$ & $20.2<$ Rating $<30.3$ & $30.3<$ Rating $<43.4$ \\
\hline
\end{tabular}

OUTSOURCE / DO NOT OUTSOURCE THE PROPOSED FUNCTION 


\section{Appendix F}

\section{Assessment Matrix (National Launch Range)}

CANDIDATE ROLE/MISSION/FUNCTION: EAST/WEST LAUNCH RANGE

RATING SCALE (PLACE "X" IN APPROPRIATE COLUMN FOR EACH ROW)

DECISION CRITERIA

CHARACTERIZATION OF FUNCTION

- Total People Involved

- DoD Civilians Positions Affected

- Rapid Technology Growth

- Inherently Government

- Inherently Commercial

- Benchmarking Completed

- Leverage With Other Gov't Agencies

- Outscourcing Development Only

- Outscourcing Development \& O\&M

- Does Viable Competition Exist $\begin{array}{lll}6 & 20 & 76\end{array}$

$\begin{array}{llllll}100 & 150 & 201 & 250 & 201 & \text { More }\end{array}$

Fewer

Than 5

to to to to to to to to Than

$\begin{array}{llllllllll}19 & 75 & 99 & 149 & 199 & 249 & 300 & 350 & 350 & \text { Summary Rationale }\end{array}$

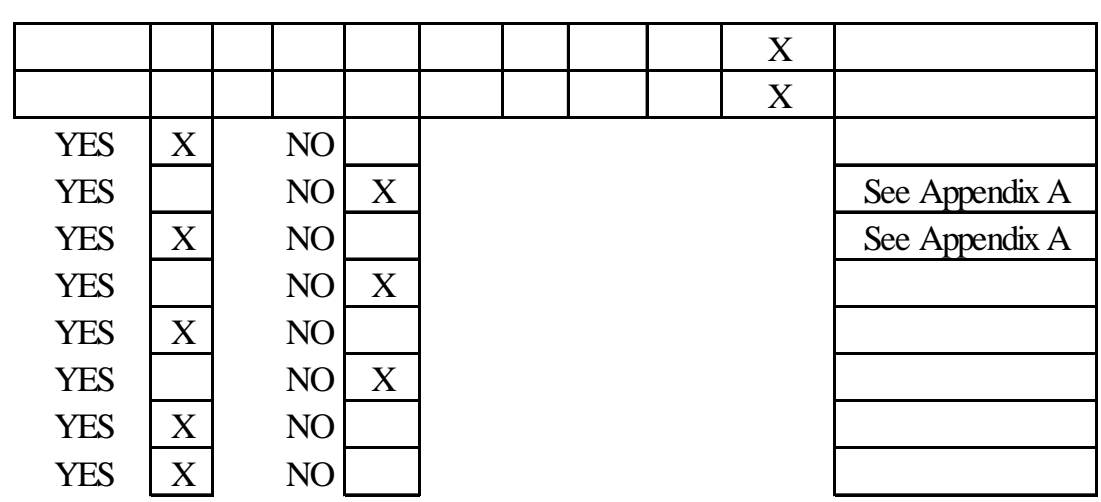


RATINGSCALE(PLACE"X" IN APPROPRIATECOLUMNFOREACHROW)

\section{DECISION CRITERIA}

\section{STRATEGICENVRONMENT}

- Consistency with HQ Policy

- Affect on:

- Long TermSupport

-- Operations

- PPBS

- Leverage with Other Agencies

- Critical Technology

-- Encryption/Decryption

-- WMD

-- Low Observables/Stealth

-- Information Management

-- Synthetic Aperture Radar

-- Hyper/Ultra spectral

--Communications

-- Supercomputing

--Other

- Congress

-- Article 10 Impacts

-- GAO Position(s)

- Industrial Base

- Consistent with Trends

- Global Competitiveness

Score $($ Higher is Better $)=$

No Impact or
Improvement to
WEIGHT $\quad$ Status Quo

025

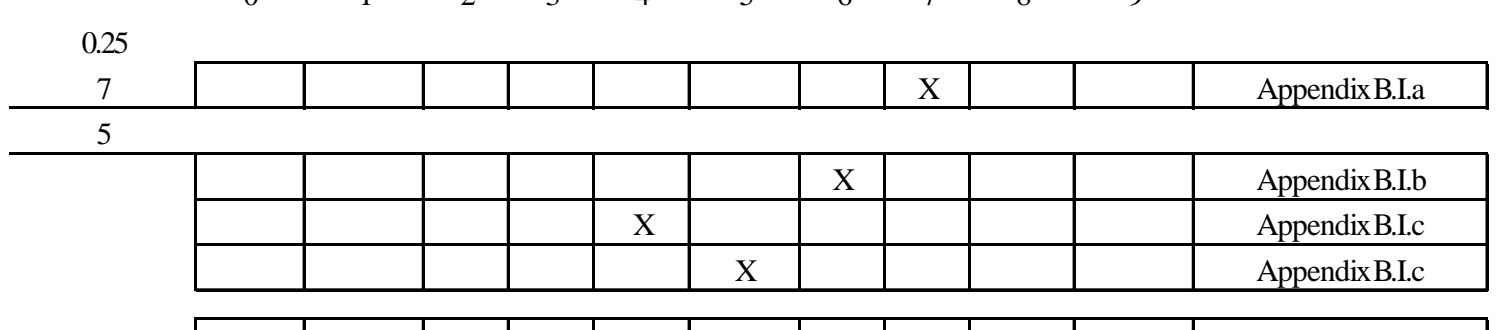

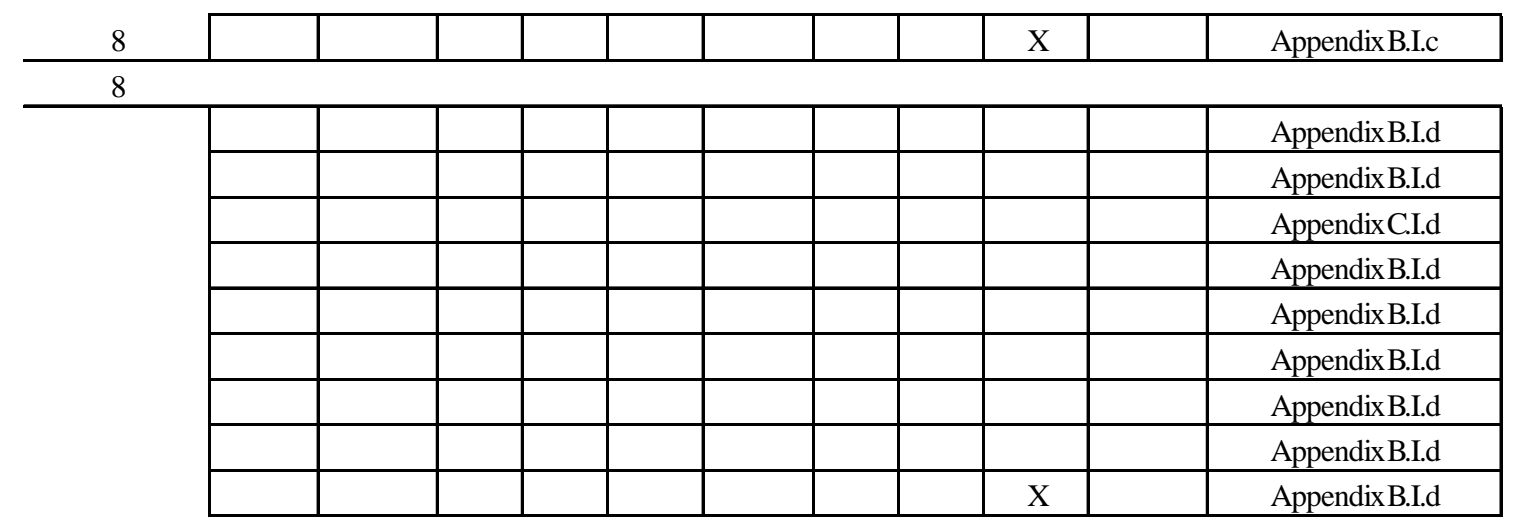

\begin{tabular}{|c|c|c|c|c|c|c|c|c|c|c|}
\hline & & & & & & $\mathrm{X}$ & & & & Appendix B.I.e \\
\hline & & & & & & & & $\mathrm{X}$ & & Appendix B.I.e \\
\hline
\end{tabular}

\begin{tabular}{|l|l|l|l|l|l|l|l|l|l|l|} 
& & & & & & & & $\mathrm{X}$ & & AppendixB.1.f \\
\hline & & & & & & & & $\mathrm{X}$ & & AppendixB.1.f \\
\hline
\end{tabular}

NOTES

43

69

13.5

Rating $=$ Score $*$ Weight $=$

10.75 


\section{CANDIDATE ROLE/MISSION/FUNCTION: EAST/WESTLAUNCHRANGE}

RATING SCALE (PLACE "X" IN APPROPRIATECOLUMN FOR EACHROW)

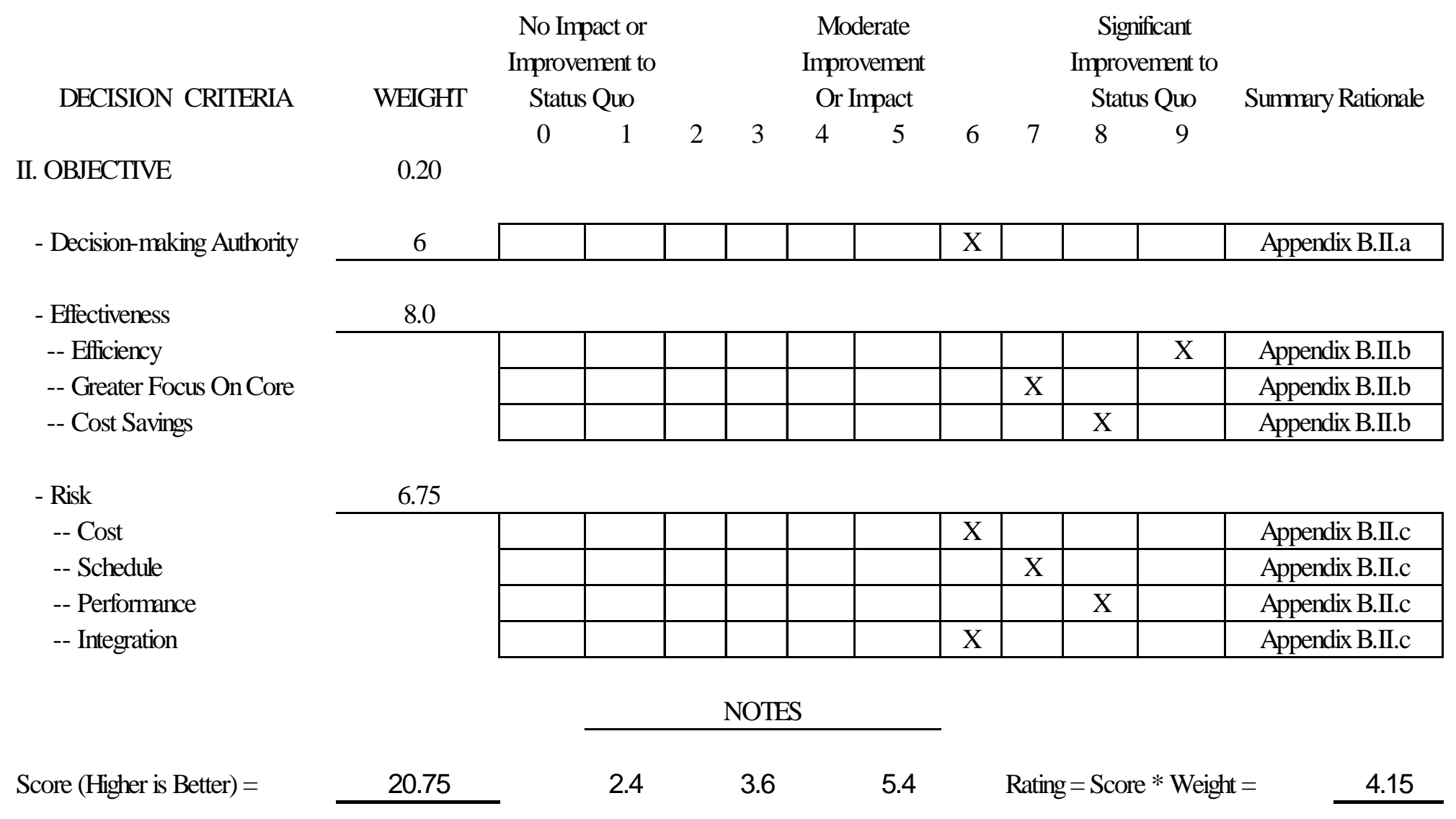


CANDIDATE ROLE/MISSION/FUNCTION: $\quad$ EAST/WESTLAUNCH RANGES

RATING SCALE(PLACE "X" IN APPROPRIATE COLUMN FOR EACH ROW)

\begin{tabular}{|c|c|c|c|c|c|c|c|c|c|}
\hline \multirow{2}{*}{ DECISION CRITERIA } & \multirow{2}{*}{ WEIGHT } & $\begin{array}{l}\text { No Impact or } \\
\text { Improvement to } \\
\text { Status Quo }\end{array}$ & & & $\begin{array}{c}\text { Moderate } \\
\text { Improvement Or } \\
\text { Impact }\end{array}$ & & & $\begin{array}{l}\text { Significant } \\
\text { Improvement to } \\
\text { Status Quo }\end{array}$ & Summary Rationale \\
\hline & & 1 & 2 & 3 & 5 & 6 & 7 & 9 & \\
\hline
\end{tabular}

III. USAF CORECOMPETENCY 0.15

- People \& Organization

\begin{tabular}{c|c|c|c|c|c|c|c|c|c|c|c|}
\hline 8 & & & & & $\mathrm{X}$ & & & & & & Appendix B.III.a \\
\hline
\end{tabular}

- Air \& Space Superiority

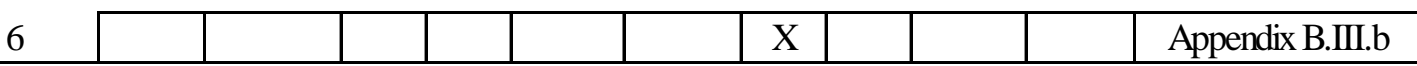

- Precision Engagement

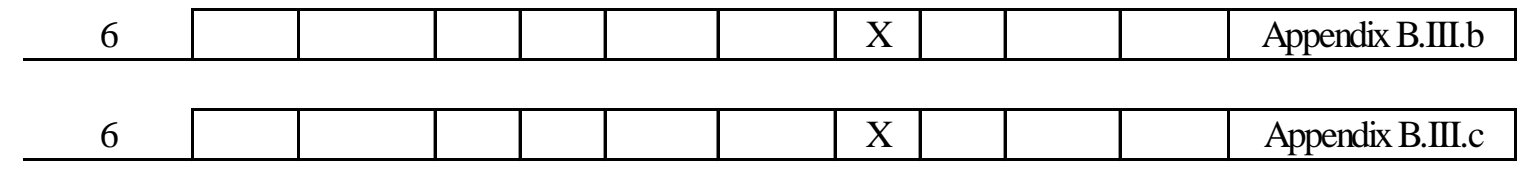

- Info Superiority

- Global Attack

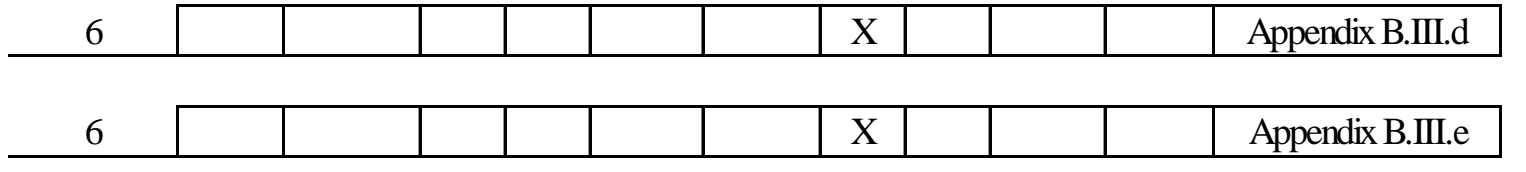

- Rapid Global Mobility

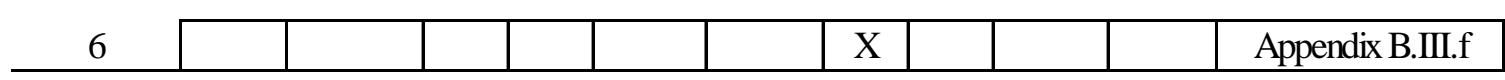

- Agile Combat Support

8

$\mathrm{X}$

Appendix B.III.g

NOTES

Score $($ Higher is Better $)=$

46

4.2

6.3

7.35

Rating $=$ Score $*$ Weight $=$

6.9 


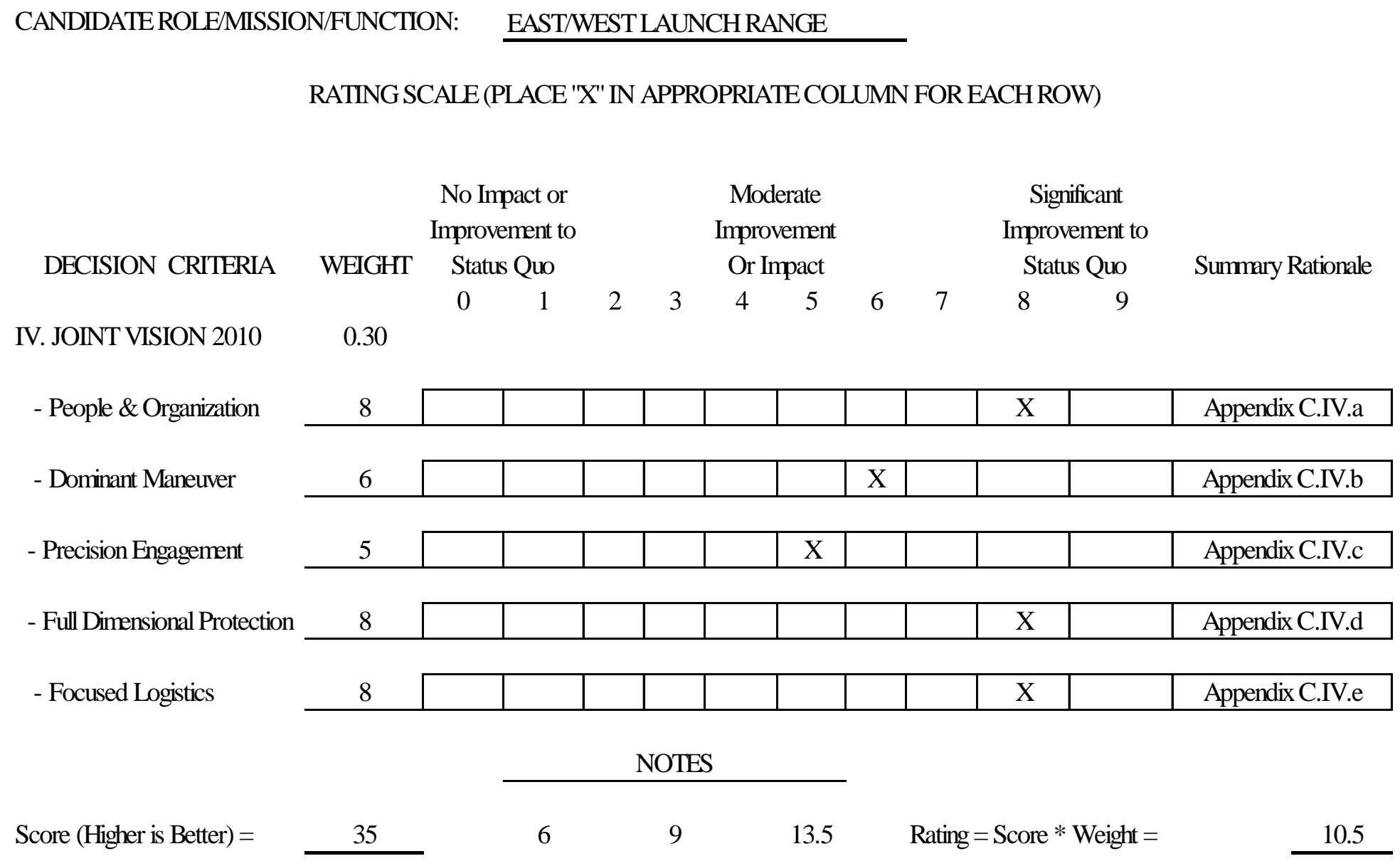




\section{CANDIDATE ROLE/MISSION/FUNCTION: $\quad$ EAST/WEST LAUNCH RANGE}

\section{RATING SCALE (PLACE "X" IN APPROPRIATE COLUMN FOR EACH ROW)}

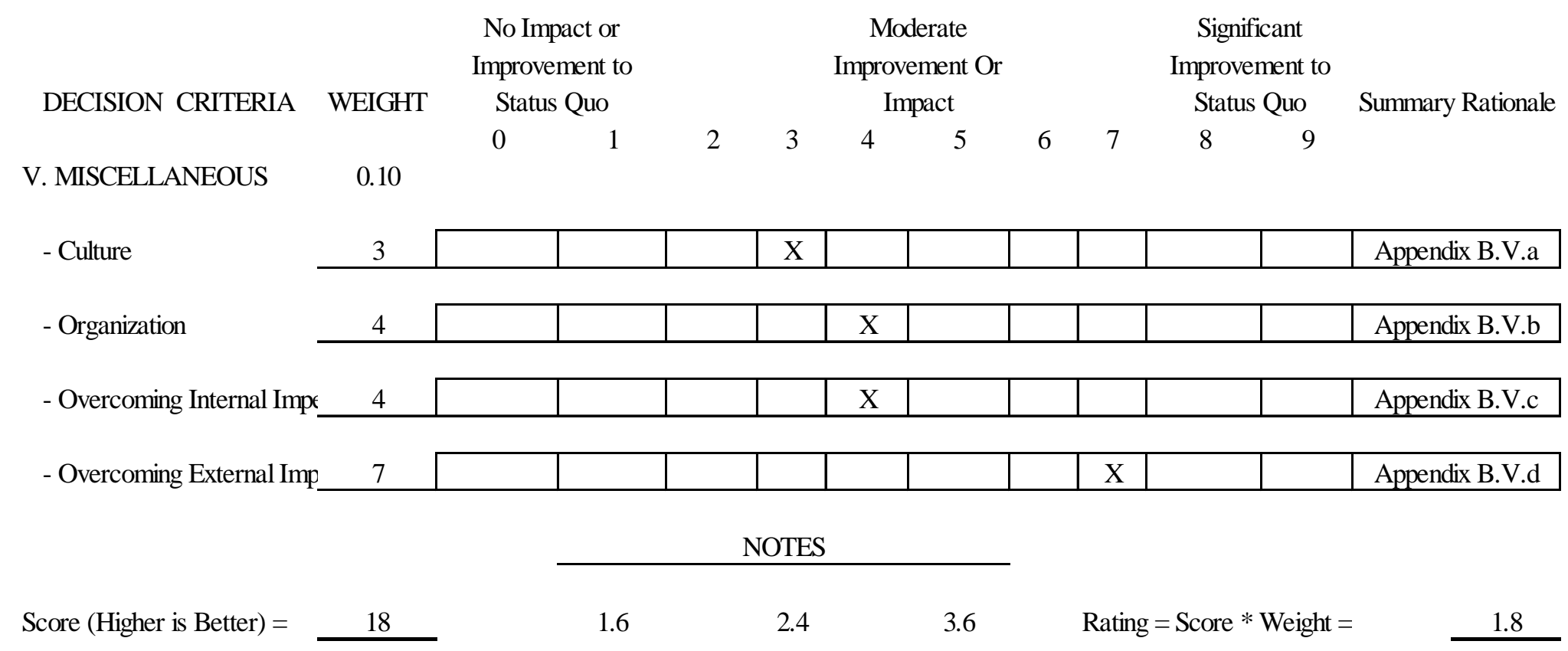


CANDIDATE ROLE/MISSION/FUNCTION:

DETERMINATION

GO (I.E. PROCEED WITH OUTSOURCING)

STUDY FURTHER (I.E. INVESTIGATE FURTHER)

STOP (I.E. DO NOT OUTSOURCE FUNCTION)
$6 \leq$ RATING $<\quad 9$

$4 \leq$ RATING $<\quad 6$

$0 \quad<$ RATING $<\quad 4$
DECISION CRITERIA

I. STRATEGIC ENVIRONMENT

II. OBJECTIVE

III. AIR FORCE CORE COMPETENCIES

IV. JOINT VISION 2010

V. MISCELLANEOUS

TOTAL

DECISION

\begin{tabular}{|c|c|c|c|c|c|}
\hline & & & \multicolumn{3}{|c|}{ NOTES } \\
\hline WEIGHT & SCORE & RATING & STOP & STUDY FURTHER & $\mathrm{GO}$ \\
\hline 0.25 & 43 & 10.75 & Rating $<6$ & $6<$ Rating $<9$ & $9<$ Rating $<13.5$ \\
\hline 0.20 & 20.75 & 4.15 & Rating $<2.4$ & $2.4<$ Rating $<3.6$ & 3.6< Rating $<5.4$ \\
\hline 0.15 & 46 & 6.9 & Rating $<4.2$ & 4. $2<$ Rating $<6.3$ & $6.3<$ Rating $<7.4$ \\
\hline 0.30 & 35 & 10.5 & Rating $<6$ & $6<$ Rating $<9$ & $9<$ Rating $<13.5$ \\
\hline 0.10 & 18 & 1.8 & Rating $<1.6$ & $1.6<$ Rating $<2.4$ & $2.4<$ Rating $<3.6$ \\
\hline 1.00 & 162.75 & 34.1 & Rating $<20.2$ & $20.2<$ Rating $<30.3$ & $30.3<$ Rating $<43.4$ \\
\hline
\end{tabular}

OUTSOURCE THE PROPOSED FUNCTION 


\section{Bibliography}

Borky, Dr. John M. United States Air Force Scientific Advisory Board, Report on A Space Roadmap for the $21^{\text {st }}$ Century Aerospace Force. Volume 1, November 1998, 28.

Breen, Tom. "Teledesic Turns to Motorola To Help Execute Ambitious Plan." Space Business News. 10 June 1998. 8.

Brower, J. Michael. "Outland: The Vogue of DoD Outsourcing and Privatization." Defense Acquisition University Journal, Acquisition Review Quarterly. Fall 1997.

Chew, James S.B., "Commercial Best Practices." Defense Acquisition University Journal, Acquisition Review Quarterly. Spring 1997.

Collings, Colonel Michael A. Chief, AF Office of Outsourcing and Privatization. Address. Air Force Association Symposium, Colorado Springs, CO, 24 May 1996.

Davis, CPA, Charles E., Elizabeth B. Davis, CFP, and Lee Ann Moore. "Outsourcing Procurement Through Payables." Management Accounting: Official Magazine of the Institute of Management Accountant 80, Issue 1 (July 1998): [38-44].

Expert Choice, Inc. web site. http://www.expertchoice.com.

Federal Computer Week. Editorial. 21 October 1996.

Holland, Lauren. "The Weapons Acquisition Process - The Impediments to Radical Reform.” Defense Acquisition University Journal, Acquisition Review Quarterly. Spring 1998.

Holt, John. "Commercializing Space." Space Policy. February 1997.

Lowry, T. USA Today. 25 March 1996. B1.

Mitchell, III, Howard R. "A Moving Issue: To Outsource or Not To Outsource," Human Resource Magazine 43, Issue 5 (May 1998): [59-68].

Money, Arthur, Assistant Secretary of the Air Force (Acquisition). Keynote address. Air Force Association Symposium, Colorado Springs, CO, 24 May 1996.

OASD Public Affairs News Release. "Defense Secretary Cohen Endorses Panel's Key Conclusion That Fundamental Infrastructure Reform is Essential to Transformation of U.S. Military." 01 December 1997.

Odeen, Phillip A. Transforming Defense - National Security in the $21^{\text {st }}$ Century, Report of the National Defense Panel. December 1997.

Proctor, Paul. "Outsourcing's Upside,“ Aviation Week \& Space Technology, 148, Issue 18 (04 May 98). [13].

Renner, CPA, Celia J., and Darin Tebbe, CPA. "Who Is Outsourcing and Why." Management Accounting: Official Magazine of the Institute of Management Accountants 80, Issue 1 (July 1998): [45-47].

Szilagyi, Jr., Andrew D., and Marc J. Wallace, Jr. Organizational Behavior and Performance, $4^{\text {th }}$ Edition. Scott, Foresman and Company; Glenview, Illinois; 1987. 
US House. Report to the Chairman, Subcommittee on Military Readiness, Committee on National Security, Base Operations, Challenges Confronting DOD as It Renews Emphasis on Outsourcing (GAO Report, GAO/NSIAD-97-86, March 1997).

US House. Defense Outsourcing, Challenges Facing DoD As It Attempts to Save Billions in Infrastructure Costs: Hearings before the Subcommittee on Readiness, Committee on National Security. (GAO Report, GAO/T-NSIAD-97-110, 12 March 1997).

US Senate. Defense Depot Maintenance, Uncertainties and Challenges DoD Faces in Restructuring Its Depot Maintenance Program: Hearings before the Subcommittee on Readiness, Committee on Armed Services. (GAO Report, GAO/T-NSIAD-97-112, 01 May 1997).

Wall Street Journal—Eastern Edition 232, Issue 114. 10 December 1998. 


\title{
DISTRIBUTION A:
}

Approved for public release; distribution is unlimited.

\author{
Air Command and Staff College \\ Maxwell AFB, Al 36112
}

